\title{
Antimicrobial Peptides as Potential Anti-Tubercular Leads: A Concise Review
}

\author{
Gabriel S. Oliveira ${ }^{1,2,3,4,+} \mathbb{D}$, Raquel P. Costa ${ }^{5,+}$, Paula Gomes ${ }^{4}\left(\mathbb{D}\right.$, Maria Salomé Gomes ${ }^{1,2,3} \mathbb{D}$, Tânia Silva ${ }^{1,2,3, * \mathbb{D}}$ \\ and Cátia Teixeira $4, *$ (iD
}

1 ICBAS-Instituto de Ciências Biomédicas Abel Salazar, Universidade do Porto, P-4050-313 Porto, Portugal; jorge.oliveira@ibmc.up.pt (G.S.O.); sgomes@ibmc.up.pt (M.S.G.)

2 I3S-Instituto de Investigação e Inovação em Saúde, Universidade do Porto, P-4200-135 Porto, Portugal

3 IBMC-Instituto de Biologia Molecular e Celular, Universidade do Porto, P-4200-135 Porto, Portugal

4 LAQV-REQUIMTE-Departamento de Química e Bioquímica, Faculdade de Ciências da Universidade do Porto, P-4169-007 Porto, Portugal; pgomes@fc.up.pt

5 LAQV-REQUIMTE-Departamento de Ciências Químicas, Faculdade de Farmácia, Universidade do Porto, P-4050-313 Porto, Portugal; raquel.piinho@gmail.com

* Correspondence: tania.silva@ibmc.up.pt (T.S.); catia.teixeira@fc.up.pt (C.T.)

+ These authors contributed equally to this work.

check for updates

Citation: Oliveira, G.S.; Costa, R.P.; Gomes, P.; Gomes, M.S.; Silva, T.; Teixeira, C. Antimicrobial Peptides as Potential Anti-Tubercular Leads: A Concise Review. Pharmaceuticals 2021, 14, 323. https://doi.org/10.3390/ ph14040323

Academic Editor: Marc Le Borgne

Received: 17 March 2021

Accepted: 31 March 2021

Published: 2 April 2021

Publisher's Note: MDPI stays neutral with regard to jurisdictional claims in published maps and institutional affiliations.

Copyright: (c) 2021 by the authors. Licensee MDPI, Basel, Switzerland. This article is an open access article distributed under the terms and conditions of the Creative Commons Attribution (CC BY) license (https:/ / creativecommons.org/licenses/by/ $4.0 /)$.
Abstract: Despite being considered a public health emergency for the last 25 years, tuberculosis (TB) is still one of the deadliest infectious diseases, responsible for over a million deaths every year. The length and toxicity of available treatments and the increasing emergence of multidrugresistant strains of Mycobacterium tuberculosis renders standard regimens increasingly inefficient and emphasizes the urgency to develop new approaches that are not only cost- and time-effective but also less toxic. Antimicrobial peptides (AMP) are small cationic and amphipathic molecules that play a vital role in the host immune system by acting as a first barrier against invading pathogens. The broad spectrum of properties that peptides possess make them one of the best possible alternatives for a new "post-antibiotic" era. In this context, research into AMP as potential anti-tubercular agents has been driven by the increasing danger revolving around the emergence of extremely-resistant strains, the innate resistance that mycobacteria possess and the low compliance of patients towards the toxic anti-TB treatments. In this review, we will focus on AMP from various sources, such as animal, non-animal and synthetic, with reported inhibitory activity towards Mycobacterium tuberculosis.

Keywords: antimicrobial peptides; anti-tubercular drugs; antibiotic resistance; mycobacteria; tuberculosis

\section{Tuberculosis: A Brief Overview \\ 1.1. Global Burden}

Tuberculosis (TB) is an airborne infectious disease caused by pathogens belonging to the Mycobacterium tuberculosis $(\mathrm{Mtb})$ complex. Characterized by its high rate of both morbidity and mortality, it has been considered a public health emergency for the last 25 years and it is one of the deadliest of human infectious diseases [1]. The pathogenicity of $M t b$ is exacerbated when in the presence of the human immunodeficiency virus (HIV), as these pathogens can potentiate one another inside of an individual host [2]. Alongside Plasmodium, a genus of parasites responsible for malaria, these pathogens form the so-called "Big Three" infectious diseases [3]. According to the latest data from the World Health Organization (WHO), around 10 million people developed TB in 2019, with an estimate of 1.2 million deaths among HIV-negative people and approximately 208,000 deaths among HIV-positive people [4]. The global incidence of active TB disease is heterogeneously distributed, with low-to-middle income countries, mostly in Africa and Southeast Asia, exhibiting higher rates of TB [4]. 
Despite all efforts to fight this disease, the increasing emergence of multidrug-resistant strains of $M t b$, renders standard treatment inefficient and emphasizes the urgency to develop new targeted therapeutic approaches [5,6]. According to the WHO, in 2019 approximately 500,000 people were infected with $M t b$ strains resistant to rifampicin, the most effective first-line antimycobacterial antibiotic. Of these, $78 \%$ were multi-drug resistant (MDR-TB), i.e., resistant to both rifampicin and isoniazid [4,6]. Additionally, extensively drug-resistant TB (XDR-TB), a more severe form of MDR-TB, has emerged. XDR-TB strains are resistant to isoniazid and rifampicin in addition to being resistant to a fluoroquinolone, as well as to at least one of the three second-line injectables currently available (amikacin, capreomycin, and kanamycin) [6]. In 2019, 12,350 cases of XDR-TB were notified [4]. Thus, antimicrobial resistance poses a serious threat to public health and requires immediate action. Within this context, antimicrobial peptides (AMP), have been coined as promising candidates for the treatment of antimicrobial infections, including TB [7-9].

\subsection{Pathogenesis}

$M t b$ enters the lungs via inhalation of aerosols. Following the entry into alveolar macrophages through receptor-mediated phagocytosis, $M t b$ arrests the acidification process of the phagosome and prevents its fusion with the lysosome, avoiding contact with potentially harmful lysosomal hydrolases, ensuring its survival [10,11]. Afterwards, $M t b$ invades the lung interstitial tissue, and dendritic cells or inflammatory monocytes transport the bacteria to the pulmonary lymph nodes for $\mathrm{T}$ cell priming, leading to recruitment of $\mathrm{T}$ and $\mathrm{B}$ cells to the lung parenchyma $[12,13]$. This promotes the release of several chemokines and cytokines, as well as the recruitment of various immune cells such as lymphocytes, which will arrange themselves in a globular structure with infected macrophages in the middle, a granuloma. A hallmark of tuberculosis, the granuloma is a double-edged sword. While it enables the host to retain the mycobacterial infection in a controlled microenvironment, it also provides the mycobacteria with an environment where it can survive through modulation of the immune response [14]. Furthermore, near its center, mature granulomas develop a hypoxic environment, which will induce the mycobacteria into a dormant state-a low metabolic activity state where the bacteria do not replicate and present a phenotypic drug resistance $[15,16]$. In many cases, the infection remains in a latent state. However, due to various genetics and environmental reasons (such as HIV infection), this latent infection can evolve into active TB, weeks or decades later. In this case, the granuloma develops a necrotic zone in its center, allowing the bacteria to exit and spread to other parts of the lungs and transmitting itself to other individuals via aerosols $[10,14]$.

\subsection{Challenges to the Standard Treatment}

Mycobacteria feature a characteristic unique and complex cell wall which renders it highly hydrophobic. Its cell envelope presents an innermost layer of peptidoglycan, composed of N-glycolylmuramic acid instead of N-acetylmuramic acid, which, in turn, is linked to a layer of arabinogalactan via a phosphodiester bridge. The presence mycolic acids, unique long-chain fatty acids ranging between 60 to 90 carbons covalently linked to arabinogalactan confers high hydrophobicity and decreased permeability to anti-TB compounds, especially when considering that lipids constitute up to $60 \%$ of the cell-wall weight $[17,18]$.

Thus far, the only available vaccine against tuberculosis is the Bacillus Calmette-Guérin (BCG), a live attenuated strain of M. bovis. However, it is not as efficient against adult forms of disease as it is in earlier ages i.e., infancy and school-age [19]. Standard treatment for TB comprises a multi-drug combination of isoniazid, rifampicin, and pyrazinamide. These three antibiotics are the basis of modern regimens [20]. Isoniazid is responsible for inhibiting the biosynthesis of mycolic acids, a major constituent of the mycobacterial cell wall [21], rifampicin inhibits RNA synthesis [22] and pyrazinamide disrupts the plasma membrane and energy metabolism [23]. During an initial two-month intensive stage, all three drugs are administered together with ethambutol, which inhibits arabinosyltransferases, a major 
key player in the synthesis of the structural component of the mycobacterial cell wall, arabinogalactan $[20,21]$. Afterwards, a four-month continuous administration of rifampicin and isoniazid is ensued. Even though these antibiotics are highly active towards actively replicating bacteria, the presence of dormant bacteria renders the treatment inefficient, requiring a prolonged drug administration, which often contributes to the development of MDR strains [24].

Treatment of MDR-TB is far more challenging, as it is more toxic, more expensive, and often unsuccessful [25]. Regimens vary from patient to patient, but they should include three drugs from group A of antibiotics (levofloxacin or moxifloxacin, bedaquiline or linezolid) and one of group B (clofazimine, cycloserine or terizidone). This means that the treatment needs to include at least four effective drugs. If the isolate shows resistance to any of these drugs, then additions from group C can be used (ethambutol, delamanid, pyrazinamide, imipenem-cilastarin or meropenem, amikacin or streptomycin, ethionamide or prothionamide and para-aminosalicylic acid). Much like the treatment regimen, the duration can vary from patient to patient, taking up to 20 months in some cases [26].

\section{Antimicrobial Peptides as a New Tool to Tackle Antibiotic-Resistant Infections}

Antimicrobial peptides (AMP, also known as host defense peptides) are essential components of the innate immune system and possess broad-spectrum activities such as antimicrobial, wound-healing, immunomodulatory and antibiofilm. They have shown to be promising drug candidates for the treatment of microbial infections, either as a monotherapy or in conjugation with other pre-existing drugs [27-30].

AMP are characterized by a short primary structure (up to 50-60 amino acid residues) and are commonly unstructured in aqueous solution [27]. However, in the presence of biological or mimetic membranes, they display remarkable structural plasticity on a very important feature, an amphipathic conformation [31,32]. This amphipathic nature that AMP possess allows interactions in both aqueous and lipid-rich environments, such as those verified in bacterial membranes [33]. Moreover, AMP are commonly cationic, presenting an overall charge of +2 to +9 [32]. Peptides with a higher charge typically display higher activity values. However, this is usually associated with high hemolysis and host toxicity. The overall positive charge allows the peptide to establish initial electrostatic interactions with the bacterial membrane, which has an overall negative charge, being one of the main drivers for peptide selectivity [34-36]. While bacterial membranes have their outer leaflet negatively charged, mammals have essentially zwitterionic phospholipids. This structural difference between the two types of membranes allows for the peptides to exert their activity preferentially on bacterial cells and not on our own [37].

Various conformations have been described in folded AMP such as $\alpha$-helical, $\beta$-sheet and extended structures. Larger AMP can also be circular, as their backbone is cyclized. Nonetheless, these are much less flexible [38]. $\alpha$-Helical AMP are a class of linear peptides known to have a broad spectrum of antimicrobial activity and a high prevalence of lysine and arginine residues, with a significant portion of hydrophobic residues $(50 \%$ or more) [39]. $\beta$-Sheet AMP are amphipathic molecules stabilized by disulfide bridges and these peptides present a much higher conformational rigidity than their $\alpha$-helical counterparts [40]. Together, $\alpha$-helices and $\beta$-sheets are the most common secondary structures found amongst all AMP. Extended AMP are a more heterogeneous group of peptides rich in certain amino acids, specifically proline, tryptophan, and arginine [41].

Several models have been proposed to describe the pathways through which AMP exert their antimicrobial action [32] and it is well known that AMP can act through different mechanisms (Figure 1). This has a major impact on their high efficacy and the broad spectrum of activity, including Gram-positive and Gram-negative bacteria, but also fungi, viruses, unicellular protozoa, and cancer cells [41]. For instance, AMP can disrupt the membrane through pore and micelles formation, binding with specific receptors or through electroporation. Moreover, they can induce cell death through interaction with internal cellular components, hijacking important processes vital to the pathogens. They can also 
interfere with the cell wall through inhibition of its biosynthesis. Lastly, they are capable of exerting antimicrobial activity without ever interacting with the pathogens, through modulation of the innate immune system [32,41-44]. Remarkably, the paradigm of how peptides act is in constant change. It is now clear that several peptides are capable of exerting activity through various mechanisms. Importantly, this may hinder the development of anti-AMP resistance.

A

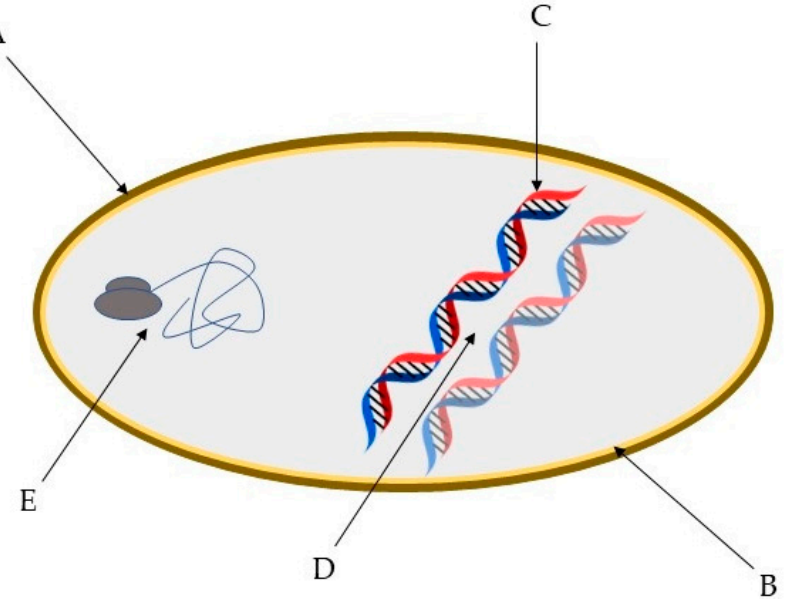

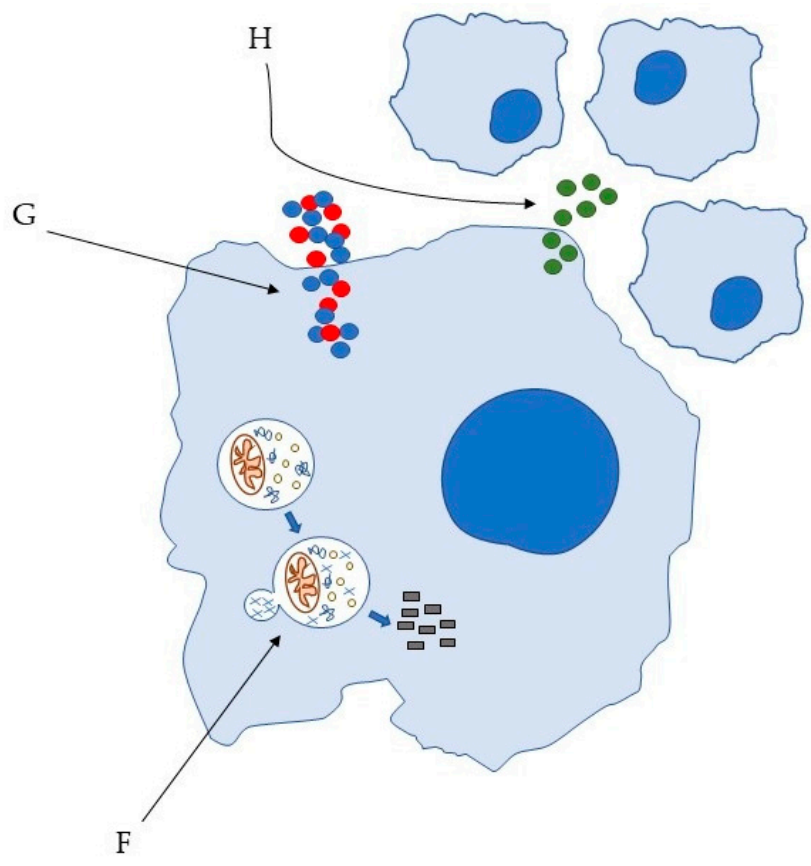

Figure 1. Some of the bacterial molecular targets of AMP: (A) bacterial cell wall; (B) bacterial membrane; (C) DNA synthesis; (D) DNA replication; (E) key bacterial protein synthesis. Some of the effects of AMP on host immune cells: (F) induction of autophagy on infected cells; (G) Overexpression of pro- and anti-inflammatory cytokines; $(\mathbf{H})$ Chemotaxis' induction $[45,46]$.

Taking into consideration the increasing resistance of $M t b$ towards conventional antibiotics and the AMP's broad spectrum of properties, we think these molecules should be further explored as potential anti-tubercular tools. In the next sections, we will review animal, non-animal and synthetic AMP with reported anti-tubercular activity and potential for clinical use.

\section{Animal AMP with Anti-Tubercular Activity}

\subsection{Cathelicidins}

Cathelicidins are a family of mammalian AMP with approximately 30 identified members. However, in humans, rhesus monkeys, rats, mice, and guinea pigs, only a single cathelicidin is expressed, named LL-37, RL-37, rCRAMP, mCRAMP, and CAP11, respectively in each species. The peptide is produced in different cells, most notably in neutrophils, in response to an infection [47].

The expression of the human CAMP gene translates into the human cationic antimicrobial peptide-18 (hCAP18). Composed by a highly conserved $N$-terminal sequence, the cathelin, and a C-terminal sequence called LL-37, this propeptide is cleaved extracellularly with the $C$-terminal portion possessing bactericidal activities [48,49]. The amphipathic $\alpha$-helical peptide, LL-37 is capable of binding to the negatively charged outer leaflet of the bacterial membrane, causing its disruption [50]. Moreover, LL-37 acts as a modulator of immune processes, such as chemotaxis, macrophage differentiation, neutrophils' physiological function and apoptosis [51].

During $M t b$ infection, LL-37 was shown to be expressed after the upregulation of vitamin D receptor resulting from the interaction of mycobacterial lipopeptide with Toll-like 
receptor (TLR)-2 [52]. Concomitantly, Mily et al. demonstrated that the oral administration of phenylbutyrate and vitamin D3 was able to induce the expression of LL-37 in macrophages and lymphocytes, with a consequent decrease in the intracellular load of $M t b$ [53]. TLR-9 activation with $M t b$ DNA, was also correlated with high LL-37 production in alveolar macrophages [54]. This induction of LL-37 has been shown to happen $18 \mathrm{~h}$ after infection in lung epithelial cells, in a dose-dependent manner, with neutrophils also being capable of efficiently producing LL-37 [54]. Albeit more resistant than other mycobacterial species, $M t b$ proved to be susceptible in vitro to LL-37, with $39 \%$ killing with $25 \mu \mathrm{g} / \mathrm{mL}$ after $24 \mathrm{~h}$ and a $60 \%$ killing with $100 \mu \mathrm{g} / \mathrm{mL}$ after $72 \mathrm{~h}$ [49], demonstrating a MIC of $\sim 5 \mu \mathrm{g} / \mathrm{mL}$ against $\mathrm{M} t b \mathrm{H37Rv}$ (Table 1) [55]. LL-37 also has immunomodulatory activities in $M t b$ infected macrophages, being capable of increasing IL-1 $\beta$ mRNA expression. It was also capable on increasing TNF- $\alpha$ levels after $4 \mathrm{~h}$ of peptide treatment. However, the effect of the peptide on TNF- $\alpha$ is time-dependent, as its levels decreased with longer peptide treatments ( $8 \mathrm{~h}$ and $24 \mathrm{~h}$ ) at any of the concentrations tested $(1,5$ and $15 \mu \mathrm{g})$. This indicates not only a proinflammatory role but also an immunosuppressing one. In fact, IL-10 and TGF- $\beta$ levels were substantially increased in infected macrophages after stimulation with LL-37, suggesting an anti-inflammatory role to LL-37, highlighting the modulation of a balanced response orchestrated by this AMP [56]. Of note, LL-37 was not found in tuberculous granulomas, questioning its role in later phases of infection [54]. It was also verified that mCRAMP was marginally more active than LL-37 against Mtb H37Rv (Table 1), and its action in vivo resulted in a non-significant decreased lung area affected by pneumonia while LL-37 showed a non-significant increase [55].

Compared to other mammals, pigs have a large reservoir of cathelicidins, for instance, the linear proline-rich PR-39 [57]. Originally isolated from the porcine small intestine, it has also been discovered in bone marrow and neutrophils [58,59]. Its mechanism of action against Escherichia coli consists of DNA and protein synthesis's inhibition [60]. PR-39 displayed a growth inhibition of $30 \%$ at $6.25 \mu \mathrm{g} / \mathrm{mL}$ and $80 \%$ at $50 \mu \mathrm{g} / \mathrm{mL}$ against $M t b$ H37Rv presenting an IC50 of $17 \mu \mathrm{g} / \mathrm{mL}$. Two drug-susceptible clinical isolates were as susceptible as the H37Rv strain. Against an MDR strain (E1380/94), the IC50 is $93 \mu \mathrm{g} / \mathrm{mL}$, with a growth inhibition of almost 50\% when treated with $100 \mu \mathrm{g} / \mathrm{mL}$. (Table 1) [61].

Additionally, a bovine cathelicidin named indolicidin has been recently tested against $M t b$. Indolicidin is a 13 amino acids long tryptophan-rich peptide, expressed in neutrophils granules, that interacts with bacterial DNA and RNA [47]. Indolicidin was capable of exerting antimycobacterial effect against three different isolates, presenting MICs of 32 against two of them and of $64 \mu \mathrm{g} / \mathrm{mL}$ against the other (Table 1), while being ineffective against the remaining isolates [62].

\subsection{Human Defensins}

Defensins are small cationic peptides with broad-spectrum activity against bacteria, viruses, and fungi, predominantly expressed in epithelial cells and neutrophils. They inhibit bacterial growth through various mechanisms, depending on the defensin itself and its target. Nonetheless, direct cell membrane disruption and targeting of DNA are two pathways commonly observed. They also exert antibacterial activities through neutralization of secreted toxins and are responsible for chemotaxis [63-65]. Characterized by the presence of a $\beta$-sheet core structure that is stabilized by six disulphide-linked cysteines, mammalian defensins are classified into three different subfamilies that differ in the position of the disulphide bonds: alpha, beta, and theta. However, the latter is not present in humans [66]. There are six known $\alpha$-defensins present in humans, four human neutrophil peptides (HNP1-4) mainly expressed by granulocytes, while the other two (HD-5 and 6) are expressed by intestinal Paneth cells. Human $\beta$-defensins (HBD) are produced by epithelial cells and several have been identified through in silico analysis [64,67].

During $M t b$ infection of alveolar epithelial cells, the expression of HBD2 was found to be upregulated [68]. Moreover, administration of L-isoleucine in murine models of TB induced a significant increase of HBD3 and HBD4, which was correlated with decreased 
bacterial load and tissue damage. This was observed not only in animals infected with $M t b$ H37Rv but also in those with an MDR strain [69]. Fattorini et al. reported that HBD1 inhibited the in vitro growth of both drug-susceptible H37Rv and MDR RM22 strains of $M t b$. Furthermore, the combination of HBD1 with isoniazid significantly reduced the in vitro growth of both strains in comparison with the peptides or isoniazid alone [70]. Upregulation of $\alpha$-defensins, more specifically HNP1-3, has also been linked with $M t b$ infection, with TB patients demonstrating higher levels of defensins HNP1-3 in plasma and bronchoalveolar fluid. Furthermore, a differentiated expression of HNP4 in comparison with latently M. tuberculosis-infected individuals has been shown [71,72]. Sharma et al. demonstrated that injection of HNP1 resulted in significant clearance of bacilli from lungs, liver and spleen of $M t b$-infected mice [73]. Additionally, the concomitant administration of HNP and HBD with conventional anti-tubercular drugs resulted in a synergistic effect, suggesting that these peptides can be used as co-adjuvants to reduce drug dose and side effects, and possibly counteract resistance development [74]. Recently, a 15-amino acid long fragment of HNP1, Pep- $\mathrm{H}$, was tested in vitro against $M t b \mathrm{H} 37 \mathrm{Rv}$, displaying an inhibitory activity of $60 \%$ and $92 \%$ at $5 \mu \mathrm{g} / \mathrm{mL}$ and $10 \mu \mathrm{g} / \mathrm{mL}$, respectively, the latter being taken as its MIC (Table 1). The peptide was also tested against intramacrophagic Mtb, demonstrating a $91 \%$ reduction of intracellular mycobacterial growth at $5 \mu \mathrm{g} / \mathrm{mL}$ [75]. Moreover, Pep-H not only led to a significant increase in the levels of RNOS and IFN- $\gamma$ but also decreases pro-inflammatory cytokines such as TNF- $\alpha$, IL-6 and MCP-1, highlighting immunomodulatory properties in addition to direct antimicrobial activity against $M t b$ [75].

\subsection{Protegrins}

The protegrins family is composed of five native AMP sequences identified in porcine leukocytes (PG-1 to PG-5) [76]. These cationic peptides are 16 to 18 amino acids long, and adopt amphipathic $\beta$-sheet structure [77,78]. Against axenically growing Mtb H37Rv, PG-1 displayed a $68.4 \% \mathrm{CFU}$ reduction at $64 \mu \mathrm{g} / \mathrm{mL}$ and $96.7 \% 128 \mu \mathrm{g} / \mathrm{mL}$, whereas against an MDR strain a significant decrease is only achieved at $128 \mu \mathrm{g} / \mathrm{mL}$ (Table 1). Nonetheless, the peptide displayed a synergistic effect when administered alongside isoniazid [70].

\subsection{Hepcidin}

Hepcidin is an AMP involved in iron homeostasis. Iron is extremely important for all living organisms, including bacteria, participating in major biological processes such as gene regulation and DNA biosynthesis [79]. It is also required to produce superoxide dismutase which protects them from the hosts' oxygen radicals [80]. Hepcidin is composed of two short $\beta$-strands that adopt a hairpin loop and is synthesized in hepatocytes in response to an infectious or inflammatory process. Responsible for negatively regulating intestinal iron absorption and macrophagic iron release, it downregulates the transport of iron through interaction with ferroportin, responsible for exporting iron to the extracellular space. This trapping of iron inside macrophages, hepatocytes and enterocytes results in disadvantageous invasion conditions for the bacteria [80-82]. Sow et al. showed that hepcidin expression is upregulated in macrophage's phagosomes following Mtb infection, inhibiting the growth through iron sequestering [83]. However, in a murine model of $M t b$ infection, liver hepcidin expression was found to be downregulated and its deficiency did not have a significant impact on the infection outcome [84].The possible role of hepcidin in host defense against $M t b$ is thus not clear.

\subsection{Lactoferrin}

Lactoferrin (LF) is an $80 \mathrm{kDa}$ iron-binding glycoprotein present in various mammalian secretions, such as saliva, tears, and milk. Its affinity for iron is 300 times higher than serum transferrin [85]. Possessing a wide array of physiological functions such as antimicrobial and immunomodulatory, it plays a significant role in the innate immune system, being associated with host defence against oral pathogens, given its presence in saliva. Several peptides with antimicrobial activities are produced by the action of proteases on LF [86]. 
One of those peptides, $\operatorname{hLF}(1-11)$, is under clinical trials to treat infections caused by Klebsiella pneumoniae, Listeria monocytogenes and methicillin-resistant Staphylococcus aureus [87]. LFcin17-30 is another LF-derived peptide with significant activity against other mycobacteria, such as Mycobacterium avium [88,89]. However, to the best of our knowledge, there are no reports on the activity of this peptide against $M t b$.

Capable of effectively interacting with membranes [90], lactoferrin was shown to be active against $M t b$ through modulation of the immune system. Using an aerosol model of infection with $M t b$ Erdman, Welsh et al. verified that mice treated with oral LF displayed a decreased bacterial dissemination to the liver and lower CFU count in the lung, accompanied by an increase in certain proinflammatory mediators, such as IL-12 [91]. Moreover, splenocytes stimulated with lipopolysaccharide (LPS) in the presence of LF increased the IL-12/IL-10 ratio, which results in the development of Th1 response, offering protection against $M t b$ [92]. Moreover, LF improves BCG-vaccine efficacy when used as an adjuvant agent, thus reinforcing the anti-tubercular potential of this protein [93,94]. However, $M t b$ is reported to be able to acquire iron through internalization of LF via GAPDH, a single receptor able to acquire iron from both transferrin and lactoferrin [95].

\subsection{Ub2-A Ubiquitin-Derived Peptide}

Ubiquitin is a protein that regulates proteasomal degradation, marking its target proteins to be destroyed in the 26S proteasome [96]. Moreover, ubiquitin is responsible for regulating the trafficking of proteins in the endocytic pathway [97]. During an infection, the fusion of the phagosome with the lysosome facilitates the killing of the invading pathogen through both oxidative and non-oxidative mechanisms. Ubiquitin-derived peptides are the primary mediators of those non-oxidative mechanisms [98]. Ubiquitin itself has no antimycobacterial activity in lysosomal extracts. However, some of its derived peptides produced by proteolytic degradation of ubiquitin, namely $\mathrm{Ub2}$, are active [99].

Against $M t b, \mathrm{Ub} 2$ possesses a MIC of $5 \mu \mathrm{M}$ (Table 1) [99]. The mechanism through which this peptide acts depends on the formation of a secondary structure involving a $\beta$-sheet. Ub2 inserts into the bacterial membranes, being capable of disrupting it and releasing the internal content [100]. Being a short peptide, $\mathrm{Ub2}$ is likely unable to span the membrane, thus it most likely acts via the micellar aggregate "detergent-like" model [101]. Nonetheless, $\mathrm{Ub} 2$ has also been shown to localize in the bacterial cytoplasm [100].

\section{7. $\mathrm{Hcl} 2$}

$\mathrm{Hcl} 2$ is a fragment of the human mitochondrial protein COX3. It was reported to strongly bind ESAT-6 [102], a protein secreted by $M t b$ that plays a key role in the mycobacterial pathogenesis, by suppressing the antigen presentation of macrophages [103].

Samuchiwal et al. demonstrated that $15 \mu \mathrm{g} / \mathrm{mL} \mathrm{Hcl} 2$ significantly inhibited the in vitro growth of $M t b \mathrm{H} 37 \mathrm{Rv}$ by disrupting the heterodimeric ESAT-6:CFP10 complex. Moreover, a drastic reduction of the mycobacterial load in THP-1 macrophages was verified, indicating that the peptide has both extracellular and intracellular activities, while at the same time setting up a strong immune response [102].

\subsection{Cathepsin G-Derived Peptides}

Cathepsin G (catG) is a neutrophil serine protease (NSP) with antimicrobial properties. Stored within the acidic granules, NSP become active only after being released into the phagocytic vacuole. Furthermore, they are also components of neutrophil extracellular traps-extracellular fibrillary structures released by neutrophils. These traps are composed of NSP alongside chromatin and facilitate pathogen arrest [104,105].

CatG demonstrated low activity against $M t b$ Erdman, in a $24 \mathrm{~h}$ incubation assay [106]. At $10 \mu \mathrm{g} / \mathrm{mL}$, the mycobacterial viability was reduced by $10 \%$ while at 50 to $100 \mu \mathrm{g} / \mathrm{mL}$ a decrease of 20 to $30 \%$ of viability was verified. On the other hand, CG117-136, a catGderived peptide and C12-CG 117-136, a fatty acid-modified version, displayed higher activities, reaching $58 \%$ decrease at $100 \mu \mathrm{g} / \mathrm{mL}$ and more than $60 \%$ decrease at $10 \mu \mathrm{g} / \mathrm{mL}$, 
respectively. Of note, the expression and activity of catG was downregulated in THP-1 monocytes exposed to the Mtb bacilli or LPS [106].

\subsection{Venom-Derived Peptides}

Natural toxins can be used therapeutically against several diseases, due to their high specificity for certain cellular components. Scorpion venom has been studied as a source of those toxins, as it is a mixture of polypeptides, nucleotides, mucoproteins among other substances [107]. Their AMP share relevant characteristics with the ones we are typically familiar with, such as the presence of hydrophobic and cationic residues, a positive net charge, and the ability to adopt an amphipathic structure [108].

Two AMP, VpAmp1.0 and VpAmp2.0, and their respective derivates, VpAmp1.1 and VpAmp2.1, from the scorpion Vaejovis punctatus, were active against $M t b \mathrm{H} 37 \mathrm{Rv}$, presenting MICs of $17.4 \mu \mathrm{M}, 5.4 \mu \mathrm{M}, 21.4 \mu \mathrm{M}, 13.6 \mu \mathrm{M}$, respectively. They were even more active against an MDR strain (except VpAmp2.0), presenting MICs of $4.2 \mu \mathrm{M}, 8.6 \mu \mathrm{M}, 30.5 \mu \mathrm{M}$ and $8.5 \mu \mathrm{M}$, respectively (Table 1) [108]. Moreover, Pin2, a 24-amino acid long $\alpha$-helical AMP extracted from the venom of the African scorpion Pandinus imperator, is anti-tubercular as well, presenting a MIC of $22.1 \mu \mathrm{M}$ against $M t b \mathrm{H} 37 \mathrm{Rv}$ and $33.1 \mu \mathrm{M}$ against an MDR strain. Two variants of Pin2, Pin2 G and Pin2 GPG were also tested, alongside two short variants of Pin 2 with 14 and 17 amino acids. The 14-amino acid long short variant of Pin2 was the best peptide, with a MIC of $11.92 \mu \mathrm{M}$ against $\mathrm{H} 37 \mathrm{Rv}$ strain and $6 \mu \mathrm{M}$ against an MDR strain (Table 1) [109].

Much like scorpion venom, snake venom has also been the target of research for finding new antibacterial compounds, as it is rich in biologically active compounds. Xie et al. showed that Vgf-1, a peptide containing three pairs of disulphide-bonds, was active against several strains of MDR Mtb with a MIC of $8.5 \mu \mathrm{g} / \mathrm{mL}$ (Table 1) [110].

\subsection{B1CTcu5}

B1CTcu5 is a 21-amino acids long AMP that belongs to the Brevinin-1 family, sharing a very similar sequence to its parental peptide. Brevinins are known for their antimicrobial activities against Gram-positive and Gram-negative bacteria. This cationic peptide was isolated from the skin secretion of the frog Clinotarsus curtipes [111,112].

Against planktonic cultures of $M t b \mathrm{H} 37 \mathrm{Rv}$ this peptide was bactericidal, presenting a MIC of $12.5 \mu \mathrm{g} / \mathrm{mL}$ (Table 1). Moreover, at its MIC, the peptide was capable of completely inhibiting $M t b$ growing inside THP1-derived macrophages. Furthermore, it was deemed as non-toxic against this cell line, proving to be a potential anti-tubercular lead [112].

Table 1. Animal AMP covered in this review, alongside their sequence, reported direct activity, and respective source.

\begin{tabular}{|c|c|c|c|c|}
\hline Peptide & Sequence & Activity & Source & Ref. \\
\hline LL-37 & LLGDFFRKSKEKIGKEFKRIVQRIKDFLRNLVPRTES & MIC (H37Rv): $\sim 5 \mu \mathrm{g} / \mathrm{mL}$ & Various human immune cells & [55] \\
\hline mCRAMP & GLLRKGGEKIGEKLKKIGQKIKNFFQKLVPQPEQ & MIC $(\mathrm{H} 37 \mathrm{Rv})-<5 \mu \mathrm{g} / \mathrm{mL}$ & Various mice immune cells & [55] \\
\hline PR-39 & RRRPRPPYLPRPRPPPFFPPRLPPRIPPGFPPRFPPRFP & $\begin{array}{c}\mathrm{IC}_{50}(\mathrm{H} 37 \mathrm{Rv}): 17 \mu \mathrm{g} / \mathrm{mL} \\
\mathrm{IC}_{50} \text { (MDR E1380/94): } 93 \mu \mathrm{g} / \mathrm{mL}\end{array}$ & $\begin{array}{l}\text { Porcine small intestine, bone } \\
\text { marrow, neutrophils }\end{array}$ & [61] \\
\hline Indolicidin & ILPWKWPWWPWRR & MIC (Mtb clinical isolate): $32 \mu \mathrm{g} / \mathrm{mL}$ & Bovine neutrophils' granules & {$[62]$} \\
\hline Pep-H & RRYGTCIYQGRLWAF & MIC (H37Rv): $10 \mu \mathrm{g} / \mathrm{mL}$ & HNP-1 in human granulocytes & [75] \\
\hline PG-1 & RGGRLCYCRRRFCVCVGR & $68.4 \% \mathrm{CFU}$ reduction at $64 \mu \mathrm{g} / \mathrm{mL}$ & Porcine leukocytes & {$[70]$} \\
\hline $\mathrm{Ub2}$ & STLHLVLRLRGG & MIC (CDC1551): $5 \mu \mathrm{M}$ & Ubiquitin in lysosomal extracts & [99] \\
\hline VpAmp1.0 & LPFFLLSLIPSAISAIKKI, amidated & $\begin{array}{c}\text { MIC (H37Rv): } 17.4 \mu \mathrm{M} \\
\text { MIC (MDR clinical isolate): } 4.2 \mu \mathrm{M}\end{array}$ & Vaejovis punctatus venom & [108] \\
\hline VpAmp2.0 & FWGFLGKLAMKAVPSLIGGNKSSSK & $\begin{array}{c}\text { MIC (H37Rv): } 5.4 \mu \mathrm{M} \\
\text { MIC (MDR clinical isolate): } 8.6 \mu \mathrm{M}\end{array}$ & Vaejovis punctatus venom & [108] \\
\hline VpAmp1.1 & FFLLSLIPSAISAIKKI, amidated & $\begin{array}{c}\text { MIC (H37Rv): } 21.4 \mu \mathrm{M} \\
\text { MIC (MDR clinical isolate): } 30.5 \mu \mathrm{M}\end{array}$ & Vaejovis punctatus venom & [108] \\
\hline VpAmp2.1 & FWGFLGKLAMKAVPSLIGGNKK & $\begin{array}{c}\text { MIC (H37Rv): } 13.6 \mu \mathrm{M} \\
\text { MIC (MDR clinical isolate): } 8.5 \mu \mathrm{M}\end{array}$ & Vaejovis punctatus venom & [108] \\
\hline Pin2 & FWGALAKGALKLIPSLFSSFSKKD & $\begin{array}{c}\text { MIC (H37Rv): } 22.1 \mu \mathrm{M} \\
\text { MIC (MDR clinical isolate): } 33.1 \mu \mathrm{M}\end{array}$ & Pandinus imperator venom & [109] \\
\hline
\end{tabular}


Table 1. Cont.

\begin{tabular}{|c|c|c|c|c|}
\hline Peptide & Sequence & Activity & Source & Ref. \\
\hline Pin2[14] & FWGLKGLKKFSKKL & $\begin{array}{c}\text { MIC (H37Rv): } 11.92 \mu \mathrm{M} \\
\text { MIC (MDR clinical isolate): } 6 \mu \mathrm{M}\end{array}$ & Pandinus imperator venom & [109] \\
\hline Vgf-1 & $\begin{array}{c}\text { ECYRKSDIVTCEPWQKFCYREVTFF } \\
\text { PNHPVYLSGCASECTETNSKWCCTTDKCNRARGG }\end{array}$ & $\operatorname{MIC}\left(\mathrm{MDR}^{*}\right): 8.5 \mu \mathrm{g} / \mathrm{mL}$ & Naja atra venom & [110] \\
\hline BICTcu5 & LIAGLAANFLPQILCKIARKC & MIC (H37Rv): $12.5 \mu \mathrm{g} / \mathrm{mL}$ & Clinotarsus curtipes skin secretion & [112] \\
\hline
\end{tabular}

* Various MDR clinically isolated strains resistant to different antibiotics.

\section{Non-Animal AMPs with Anti-Tubercular Activity}

4.1. Bacterial Peptides

\subsubsection{Nisin A and Lacticin 3147}

Nisin A and lacticin 3147 are two of the best characterized lantibiotics. Ribosomally synthesized peptides produced by the Gram-positive bacteria Lactococcus lactis, lantibiotics have had their use well-documented in food, animal, and human applications [113]. Nisin A is a 34-amino acids long peptide with reported activity against several bacteria, including mycobacteria. It acts on the cytoplasmic membrane through pore formation and through interruption of cell wall biosynthesis after establishing contact with the lipid II molecule [114]. Lacticin 3147, much like nisin, is active against many drug-resistant bacteria, including clinically relevant mycobacteria. It is a "two-peptide lantibiotic" since it acts through the synergistic action of $\operatorname{Ltn} \alpha$ and $\operatorname{Ltn} \beta, 30$ and 29 amino acids in length, respectively. It acts via the formation of pores that are selective to $\mathrm{K}^{+}$ions and inorganic phosphate, which leads to the dissipation of the membrane potential and hydrolysis of internal ATP, culminating in cell death through the collapse of the $\mathrm{pH}$ gradient [115].

Carrol et al. reported that both nisin A and lacticin 3147 are active in vitro against $M t b$. Lacticin 3147 presented an $\mathrm{IC}_{90}$ of $7.5 \mu \mathrm{g} / \mathrm{mL}$ against $M t b \mathrm{H} 37 \mathrm{Ra}$ (Table 2). This peptide displayed a $98 \%$ growth inhibition at $60 \mu \mathrm{g} / \mathrm{mL}$, while nisin A could only inhibit $76.3 \%$ of the culture growth at the same concentration (Table 2) [116]. However, it has been demonstrated that mutated variants of nisin, nisin K22S (nisin S), nisin K22T (nisin T) and nisin M21V (nisin V) were more potent than nisin A against Mtb H37Ra. Nisin V was 10\% more potent, while nisin $\mathrm{T}$ and nisin $\mathrm{S}$ reduced the mycobacterial growth by $24 \%$ and $26 \%$, respectively, when compared to nisin A (Table 2) [117].

\subsubsection{Mutacin 1140}

Mutacin 1140, typically known as MU1140, is derived from Streptococcus mutans JH1140, has 22 amino acids and presents low levels of toxicity, a high degree of stability, and good pharmacokinetics $[118,119]$. Its mode of action is thought to be similar to nisin, as it is believed that MU1140 interacts with lipid II and consequently inhibits cell wall synthesis [120]. Noteworthy, MU1140 is an Oragenics Inc. (Tampa, FL, USA) lead compound, successfully concluding pre-clinical trials after displaying promising activity against both active and latent $M t b$ [8].

\subsubsection{Lasso Peptides}

Lasso peptides are a subclass of ribosomally synthesized and post-translationally modified peptides characterized by a stable structure. With a broad spectrum of bioactivity, lasso peptides have been associated with antimicrobial action, including relevant antitubercular efficacy [121].

Lassomycin is a peptide that belongs to the subclass of lasso peptides and it is extracted from Lentzea kentuckyensis sp. It displays potent activities against various strains of $M t b$, including MDR and XDR strains, ranging from 0.8 to $3 \mu \mathrm{g} / \mathrm{mL}$ (Table 2) [122]. It acts by targeting the ATP-dependent protease ClpC1P1P2, an important regulatory enzyme that destroys key cellular proteins. The inhibition of this proteolysis is a novel mechanism through which a peptide acts and it is highly detrimental to bacteria, as proven by this peptide's anti-tubercular activity [122]. 
Lariatins A and B, both derived from Rhodococcus jostii K01-B0171, are other AMP that belong to the lasso peptides subclass and have reported anti-mycobacterial activities [123]. Even though both lariatin A and B are active against $M$. smegmatis, only lariatin A was tested against $M t b \mathrm{H} 37 \mathrm{Rv}$ in vitro, displaying a MIC of $0.39 \mu \mathrm{g} / \mathrm{mL}$ (Table 2) [123].

\subsubsection{Streptomyces-Derived Peptides}

Ever since the description of S-520's activity in the 1970s, Streptomyces has been a bacterial source of peptides with antimycobacterial properties [124]. Most importantly, these bacteria are the source of streptomycin, the first approved antibiotic used to treat tuberculosis [125].

More recently, some AMP originated from Streptomyces have been identified as antitubercular. An actinomycete extract conveyed identification of hytramycins I and V, two cyclic peptides that originated from Streptomyces hygroscopicus. These peptides displayed potent in vitro activities against $M t b \mathrm{H} 37 \mathrm{Rv}$, with MICs of 6 and $11.3 \mu \mathrm{g} / \mathrm{mL}$ under normal conditions and MICs of 1.5 and $2.4 \mu \mathrm{g} / \mathrm{mL}$ under hypoxic conditions, respectively (Table 2). Hytramycin I was further shown to present MICs lower than $10 \mu \mathrm{g} / \mathrm{mL}$ against $7 \mathrm{Mtb}$ MDR strains [126].

Cyclomarin A is another cyclic AMP that exhibited activity against several Mtb MDR isolates, killing more than $90 \%$ of nonreplicating hypoxic mycobacteria at $2.5 \mu \mathrm{M}$ (Table 2). It was found to act through targeting of the $\mathrm{ClpC} 1$ subunit of the caseinolytic protease, a regulatory subunit [127]. Sansanmycin A, an AMP that belongs to the novel class of uridylpeptide antibiotics that originate from Streptomyces sp. SS, presented a MIC of $16 \mu \mathrm{g} / \mathrm{mL}$ against $M t b \mathrm{H} 37 \mathrm{Rv}$, and $8 \mu \mathrm{g} / \mathrm{mL}$ against $M t b 2199$, a strain isolated from patients in China resistant to both rifampicin and isoniazid (Table 2) [128].

\subsection{Fungal Peptides}

\subsubsection{NZX}

Fungal defensins are potent AMP with low toxicity and high serum stability. Plecstasin was the first fungal defensin identified. Derived from the fungus Pseudoplectania nigrella, it is a 40-amino acid long peptide with described activity against Gram-positive bacteria, including MDR strains, such as Staphylococcus aureus. Through the method of residue substitution, several variants of plecstasin were generated such as NZX, with reported anti-tubercular activities and high resistance to proteases' action [129].

NZX demonstrated a concentration-dependent activity, with a MIC of $6.3 \mu \mathrm{M}$ against $\mathrm{M} t b \mathrm{H} 37 \mathrm{Rv}$ and an MDR isolate. Against two clinical isolates, it displayed MICs of $6.3 \mu \mathrm{M}$ and $3.2 \mu \mathrm{M}$, with $6.3 \mu \mathrm{M}$ being also the MIC obtained against an MDR isolate (Table 2) [129]. In vivo, an intra-tracheal administration of $0.83 \mathrm{mg}$ of NZX during 5 days, after a 19-day infection of BALB/c mice with $M t b$, reduced the number of CFUs present in the lungs by $46 \%$ compared to the control animals. These results are comparable to the effects of rifampicin, which strongly supports the peptide's therapeutic potential as a future anti-tubercular agent [129].

\subsubsection{Trichoderins}

In 2010, using a screening system, Pruksakorn et al. were able to isolate three new aminolipopeptides named trichoderins A, A1 and B. These were isolated from a culture of marine sponge-derived fungus of Trichoderma sp. 05FI48 with the premise of being AMP with anti-dormant mycobacterial properties [130].

Using both aerobic and hypoxic conditions, Pruksakorn et al. were able to assess that all three trichoderins had the same activity against $M t b \mathrm{H} 37 \mathrm{Rv}$ in both conditions, with MICs of $0.12 \mu \mathrm{g} / \mathrm{mL}, 2 \mu \mathrm{g} / \mathrm{mL}$ and $0.13 \mu \mathrm{g} / \mathrm{mL}$ for trichoderin $\mathrm{A}, \mathrm{A} 1$ and B, respectively (Table 2) [130]. Trichoderin A, the peptide with the highest efficacy, was found to exert this potent antimycobacterial activity through inhibition of the mycobacterial ATP synthesis [131]. 


\subsection{Plant-Derived Peptides \\ Capsicum Defensins}

As mentioned before, many AMP are part of an innate response elicited by most living forms, and plants are not an exception. Capsicum plants, specifically, have been considered as a possible research target in the search for new proteins and peptides that help defend plants against invading pathogens, given their already described antibacterial compounds [132,133].

Gebara et al. identified two fractions from an isolate of pepper fruits of Capsicum annuum with antimycobacterial activity. These two fractions demonstrated two protein bands at $\sim 5$ and $\sim 6 \mathrm{kDa}$. They were later characterized as the result of two defensins$\mathrm{CaDef}{ }_{2.1}$ and $\mathrm{CaDef} \mathrm{De}_{2.2}$ [134]. Fraction F2, containing $\mathrm{CaDef} \mathrm{D}_{2.1}$ and $\mathrm{CaDef} \mathrm{D}_{2.2}$, demonstrated an $\mathrm{IC}_{50}$ of $39.2 \mu \mathrm{g} / \mathrm{mL}$ against $M t b \mathrm{H} 37 \mathrm{Rv}$ (Table 2). F3, possessing $C a$ Def $_{2.2}$, was not able to maintain its potency, demonstrating an $\mathrm{IC}_{50}>100 \mu \mathrm{g} / \mathrm{mL}$. However, against the hypervirulent $M t b \mathrm{M} 299$ strain, no fraction could present an $\mathrm{IC}_{50}<100 \mu \mathrm{g} / \mathrm{mL}$ [134].

Table 2. Non-animal AMP covered in this review, alongside their sequence, reported direct activity, and respective source.

\begin{tabular}{|c|c|c|c|c|}
\hline Peptide & Sequence & Activity & Source & Ref. \\
\hline Nisin A & $\begin{array}{l}\text { I-Dhb-AI-Dha-LA-Abu-PGAK-Abu-GALMGANMK-Abu- } \\
\text { A-Abu-ANASIHV-Dha-K }\end{array}$ & $\mathrm{IC}_{90}(\mathrm{H} 37 \mathrm{Ra}):>60 \mu \mathrm{g} / \mathrm{mL}$ & Lactococcus lactis & [116] \\
\hline Nisin S & $\begin{array}{l}\text { I-Dhb-AI-Dha-LA-Abu-PGAK-Abu-GALMGANMS-Abu- } \\
\text { A-Abu-ANASIHV-Dha-K }\end{array}$ & $\begin{array}{l}\text { Mycobacterial growth reduced in } \\
26 \% \text { compared to Nisin A }\end{array}$ & Derived from Nisin A & [117] \\
\hline Nisin T & $\begin{array}{c}\text { I-Dhb-AI-Dha-LA-Abu-PGAK-Abu-GALMGANMT-Abu- } \\
\text { A-Abu-ANASIHV-Dha-K }\end{array}$ & $\begin{array}{l}\text { Mycobacterial growth reduced in } \\
24 \% \text { compared to Nisin A }\end{array}$ & Derived from Nisin A & [117] \\
\hline Nisin V & $\begin{array}{c}\text { I-Dhb-AI-Dha-LA-Abu-PGAK-Abu-GALMGANVK-Abu- } \\
\text { A-Abu-ANASIHV-Dha-K }\end{array}$ & $\begin{array}{l}\text { Mycobacterial growth reduced in } \\
10 \% \text { compared to Nisin A }\end{array}$ & Derived from Nisin A & [117] \\
\hline Lacticin 3147 & $\begin{array}{c}\text { Equimolar mixture of Lan } \alpha \text { [AA-Dhb-N-Dhb-F-(D- } \\
\text { Ala)LADYWGNNGAWA-Abu-L-Abu-HEAMAWAK] and } \\
\text { Lan } \beta \text { [[CH } \mathrm{CH}_{3}-\mathrm{CH}_{2} \text {-CO-CO-Dhb-PA-Dhb-PAI-(D-Ala)IL-(D- } \\
\text { Ala)AYIATNTAP-Abu-TKA-Abu-RAA] }\end{array}$ & $\mathrm{IC}_{90}(\mathrm{H} 37 \mathrm{Ra}): 7.5 \mu \mathrm{g} / \mathrm{mL}$ & Lactococcus lactis & [116] \\
\hline Lassomycin & GLRRLFADQLVGRRNI- $\mathrm{CO}_{2} \mathrm{CH}_{3}$ & $\begin{array}{l}\text { MICs (MDR and XDR strains *): } \\
0.8-3 \mathrm{mg} / \mathrm{mL}\end{array}$ & Lentzea kentuckyensis sp. & [122] \\
\hline Lariatin A & cyclo-(GSQLVYRE)-WVGHSNVIKP & MIC (H37Rv): $0.39 \mu \mathrm{g} / \mathrm{mL}$ & Rhodococcus jostii K01-B0171 & [123] \\
\hline Hytramycin V & cyclo-[(NMe-Ala)-(D-Pip)-L-(D-Val)-Pip-(D-Pip)] & $\begin{array}{l}\text { MIC Normal (H37Rv): } 11.37 \mu \mathrm{g} / \mathrm{mL} \\
\text { MIC Hypoxic (H37Rv): } 2.4 \mu \mathrm{g} / \mathrm{mL}\end{array}$ & Streptomyces hygroscopicus & [126] \\
\hline Hytramycin I & cyclo-[(NMe-Ala)-(D-Pip)-L-(D-Allo-Ile)-Pip-(D-Pip)] & $\begin{array}{l}\text { MIC Normal (H37Rv): } 6 \mu \mathrm{g} / \mathrm{mL} \\
\text { MIC Hypoxic (H37Rv): } 1.5 \mu \mathrm{g} / \mathrm{mL}\end{array}$ & Streptomyces hygroscopicus & [126] \\
\hline Cyclomarin A & $\begin{array}{c}\text { cyclo-[(tert-prenylated } \\
\beta \text {-hydroxy-Trp)-(NMe-5-hydroxy-Leu)-A-( } \beta \text {-methoxy- } \\
\text { Phe)-V-(NMe-Leu)-(2-amino-3,5-dimethyl-4-hexeneoic } \\
\text { acid)] }\end{array}$ & $\begin{array}{l}>90 \% \text { of the inoculum killed in five } \\
\text { days at } 2.5 \mu \mathrm{M}\end{array}$ & Streptomyces sp. (CNB-982) & [127] \\
\hline Sansanmycin A & Not available & $\begin{array}{l}\text { MIC (H37Rv): } 16 \mu \mathrm{g} / \mathrm{mL} \\
\text { MIC (2199): } 8 \mu \mathrm{g} / \mathrm{mL}\end{array}$ & Streptomyces sp. SS & [128] \\
\hline NZX & $\begin{array}{l}\text { GFGCNGPWSEDDIQCHNHCKSIKGYKGGYC } \\
\text { ARGGFVCKCY }\end{array}$ & $\begin{array}{c}\text { MIC (H37Rv and clinical MDR } \\
\text { isolate): } 6.3 \mu \mathrm{M} \\
\text { MIC (clinical isolates): } 3.2-6.3 \mu \mathrm{M}\end{array}$ & $\begin{array}{l}\text { Derived from plecstasin of } \\
\text { Pseudoplectania nigrella }\end{array}$ & [129] \\
\hline Trichoderin A & (MDA)-P-(AHMOD)-Aib-Aib-IL-Aib-Aib-(AMAE) & MIC (H37Rv): $0.12 \mu \mathrm{g} / \mathrm{mL}$ & Trichoderma sp. 05FI48 & [130] \\
\hline Trichoderin A1 & (MDA)-P-(AHMOD2)-Aib-Aib-IL-Aib-Aib-(AMAE) & MIC (H37Rv): $2 \mu \mathrm{g} / \mathrm{mL}$ & Trichoderma sp. 05FI48 & [130] \\
\hline Trichoderin B & (MDA)-P-(AHMOD)-Aib-Aib-LL-Aib-Aib-(AMAE) & MIC (H37Rv): $0.13 \mu \mathrm{g} / \mathrm{mL}$ & Trichoderma sp. 05FI48 & [130] \\
\hline $\mathrm{CaDef}_{2.1}$ & ICEALSGNFKGLCLSSRREGFTDGSCIGFRLQCFCTKPCA & \multirow{2}{*}{ MIC (H37Rv): $39.2 \mu \mathrm{g} / \mathrm{mL}$} & \multirow{2}{*}{ Capsicum annuum } & \multirow{2}{*}{134} \\
\hline $\mathrm{CaDef}_{2.2}$ & SKYFTGLCWTDSSCRKVCIEKDFQDGHCSKIQR & & & \\
\hline
\end{tabular}

Abu: $\alpha$-aminobutyric acid; AHMOD: $(2 S, 4 S, 6 S)$-2-amino-6-hydroxy-4-methyl-8-oxodecanoic acid; AHMOD2: (2S,4R)-2-amino-4-methyl8-oxodec-6-enoic acid; Aib: 2-aminoisobutyric acid; AMAE: (S)-2-((2-aminopropyl(methyl)amino)etanol; Dha: dehydroalanine; Dhb: dehydrobutyrine; MDA: $(R)-2$-methyldecanoic acid; Pip: piperazic acid; ${ }^{*}$ various MDR and XDR strains resistant to different antibiotics.

\section{Synthetic AMPs with Anti-Tubercular Activity}

\subsection{De Novo Designed Peptides}

In the de novo design of synthetic AMPs, important characteristics such as an amphipathic conformation and a cationic net charge will be favored. However, subtle properties selected by evolution may be missing, which may reflect on different folding patterns or the lack of specificity of these AMP [135]. On the other hand, de novo designed non-natural 
peptides and peptidomimetics may exhibit improved pharmacokinetics, including higher resistance to proteolytic degradation in vivo [136].

Peptoids, also called oligo-N-substituted glycines, are peptidomimetics with a backbone identical to natural proteins but with amino acid side chains attached to the backbone nitrogen instead of the $\alpha$-carbon. This confers the peptoid high resistance to proteases [137]. Kapoor et al. showed that $1-\mathrm{C} 13_{4 \mathrm{mer}}$, a designed tetrameric, alkylated and cationic peptoid, was highly active against $M t b \mathrm{H} 37 \mathrm{Rv}$, presenting a MIC of $6.6 \mu \mathrm{M}$ (Table 3) while displaying no cytotoxicity, whereas an unalkylated analogue was inactive [138].

In 2016, Hicks et al. designed de novo AMPs to overcome certain issues such as bioavailability and metabolic stability. These authors incorporated $\mathrm{C}^{\alpha}$-tetra-substituted $\alpha$-amino acids, known to induce stable secondary structures. Ten peptides were tested, all of them displaying a MIC of $<41 \mu \mathrm{M}$ against H37Rv, MDR, and XDR strains of $M t b$, with the most active peptide presenting a MIC of $4.92 \mu \mathrm{M}$ against all three strains (Table 3) [139].

$\mathrm{M}(\mathrm{LLKK})_{2} \mathrm{M}$ is another synthetic $\alpha$-helical peptide designed with the primary backbone sequence $(X X Y Y) n$ where $X$ is a hydrophobic amino acid, $Y$ is a cationic amino acid and $\mathrm{n}$ is the number of repeat units, which was proven to be active in vitro against $M+b$ with a MIC of $125 \mu \mathrm{g} / \mathrm{mL}$ against H37Rv strain and $62.5 \mu \mathrm{g} / \mathrm{mL}$ against MDR CSU87 strain (Table 3). When combined with rifampicin this peptide demonstrated a synergistic effect, delaying the emergent rifampicin-resistance [140].

D-LAK120 peptides are a family of six AMP composed of 25 D-amino acids with a charge angle of $120^{\circ}$ that adopt a left-handed $\alpha$-helix conformation [141]. Their activity against drug-resistant strains of $M t b$ was assessed both in vitro and ex vivo by Lan et al. [142]. All six peptides successfully inhibited the growth of $M t b$ in vitro in a concentration-dependent manner. Four of these peptides significantly inhibited the growth of $M t b$ inside THP- 1 cells, measured after 7 days in culture with $6.25 \mu \mathrm{M}$ D-LAK120 peptides. A combination of one of the peptides, D-LAK 120-A, with isoniazid potentiated the effect against a drug-resistant strain of $M t b$ [142].

Ramón-García et al. also reported anti-tubercular activities through de novo synthesized cationic, short, nontoxic AMP [143]. Out of 49 peptides, twelve had an $\mathrm{IC}_{90}$ lower than $5 \mu \mathrm{M}$ while the most potent peptide (WKWLKKWIK) had an IC ${ }_{90}$ of $1 \mu \mathrm{M}$ (Table 3) [143].

Silva et al. demonstrated that the addition of cinnamic acids to the $\mathrm{N}$-terminus of seven cationic AMP enhanced their antimycobacterial potency, against $M t b \mathrm{H} 37 \mathrm{Rv}$ and a MDR strain, with Cin+CAMP1 and Cin+CAMP3 being the most potent peptides [144]. They displayed an $\mathrm{IC}_{95}$ of $44.33 \mu \mathrm{M}$ and $38.51 \mu \mathrm{M}$, respectively, and an $\mathrm{IC}_{50}$ of $0.69 \mu \mathrm{M}$ and $2.41 \mu \mathrm{M}$ against $M t b$ H37Rv. Furthermore, against a MDR strain, Cin+CAMP1 and Cin+CAMP3 displayed an $\mathrm{IC}_{50}$ of $2.77 \mu \mathrm{M}$ and $0.60 \mu \mathrm{M}$ (Table 3) [144].

Iztli Peptide 1 (IP-1) is a synthetic hunter-killer peptide-a molecule that comprises a ligand peptide (hunter sequence) and a cationic antibacterial peptide (killer sequence) [145]. Coyotl et al. demonstrated that IP- 1 was able to directly kill Mtb H37Rv and a clinical MDR isolate CIBIN99 in vitro with an $\mathrm{IC}_{50}$ of $99.27 \mu \mathrm{M}$ and $92.66 \mu \mathrm{M}$, respectively (Table 3). Treating infected animals with $\mathrm{H} 37 \mathrm{Rv}$ strain led to a significant reduction of the lung bacillary load (greater than $80 \%$ ) and a slight reduction of pneumonia through an every other day intratracheal administration of $8 \mu \mathrm{g}$ of IP- 1 for one month, after two months of infection. Similar results were observed for the MDR strain. Furthermore, this peptide was able to induce autophagy in macrophages and HEK293T (a variant from the human embryonic kidney 239 cells) and induce the production of TNF- $\alpha$. These data prove that this peptide might be useful in treating $M t b$ infections through induction of the protective cytokine TNF- $\alpha$ while at the same time inducing autophagy in infected macrophages and through direct killing of $M t b$ [146].

\subsection{Nature-Inspired Synthetic Peptides}

Rivas-Santiago et al. assessed the inhibitory activity of three synthetic peptides against $M t b-\mathrm{E} 2$, E6 and CP26 [55]. E2, an octapeptide, and E6, a dodecapeptide, are the result of peptide array and substitution screenings on bactenecin, a bovine dodecapeptide. CP26 is a 
$\beta$-helical 26-amino acids long, derived from a hybrid peptide containing the amphipathic $\alpha$ helical $N$-terminal region of cecropin A and the hydrophobic $N$-terminal of the bee venom melittin. These peptides were proven effective in reducing the mycobacterial growth of both susceptible (H37Rv) and MDR strains of Mtb with MICs of 2.1 (CP26), 2.6 (E2), and $3.2 \mu \mathrm{g} / \mathrm{mL}$ (E6) (Table 3) [55].

Through substitution, scrambling and screening for the capacity to induce chemokines like macrophage chemotactic protein-1 (MCP-1), three immunomodulatory IDR peptides, IDR-HH2, IDR-1002 and IDR-1018 were formulated, synthesized, and tested against Mtb in vitro [147]. IDR-1018 was the most efficient, with a MIC of $16 \mu \mathrm{g} / \mathrm{mL}$ followed by 1002 and $\mathrm{HH} 2$, both with a MIC of $29.3 \mu \mathrm{g} / \mathrm{mL}$ against $M t b \mathrm{H} 37 \mathrm{Rv}$ (Table 3 ). These peptides were not toxic towards monocytes in the concentrations tested (up to $128 \mu \mathrm{g} / \mathrm{mL}$ ). Furthermore, following 60 days of infection, $\mathrm{HH} 2$ and IDR-1018 were able to significantly reduce by 3 to 5 -fold CFU counts of MDR in infected mice through an intratracheal instillation of $32 \mu \mathrm{g}$ in $100 \mu \mathrm{L}$ of saline solution three times a week for up to 4 weeks, whereas 1002 showed no significant effect [147].

Li et al. not only tested the activity of sansanmycin A against $M t b$, already mentioned above in Section 4.1.4, but also tested the activity of sansanmycin A derivatives [128]. The introduction of various substituents at the $\mathrm{N}$-terminus was performed to increase lipophilicity and, consequently, led to an improved passive diffusion through the cytoplasmic membrane, given that its mode of action consists of inhibiting the MraY translocase present in the bacterial membrane. Out of 17 derivatives, only one was more effective than its parental peptide, the analogue $1 \mathrm{~d}$, possessing an isopropyl group. Against both $M t b$ H37Rv and 2199 strains, this synthetic derivative had a MIC of $8 \mu \mathrm{g} / \mathrm{mL}$ (Table 3) [128].

AK15-6 is an isomer of the mycobacteriophage-derived AK15 peptide, formed by a rearrangement of the amino acids of the AK15's helix to increase its hydrophobic moment [148]. Both AK15 and its synthetic isomer showed selective toxicity towards Mtb, with no activity against Gram-negative and Gram-positive bacteria below $150 \mu \mathrm{g} / \mathrm{mL}$. Against Mtb H37Rv, AK15 displayed a MIC of $37.5 \mu \mathrm{g} / \mathrm{mL}$ while AK15-6 demonstrated a MIC of $18.75 \mu \mathrm{g} / \mathrm{mL}$ (Table 3). Both peptides inhibited mycobacterial growth through membrane disruption and trehalose 6,6'-dimycolate (TDM)-binding (the most abundant glycolipid produced on the surface of mycobacteria). Furthermore, they displayed synergistic effects with rifampicin. In the lungs of $M t b$-infected mice, an intravenous injection of $10 \mathrm{mg} / \mathrm{kg}$ of peptides once a day over 7 days post infection reduced both the bacterial load and the number and size of tuberculous granulomas 4 weeks post infection. AK15-6 treatment inhibited $79 \%$ of the mycobacterial load, $72.2 \%$ granuloma number and $67.5 \%$ granuloma size in comparison with the control (PBS-treated mice). The peptides were also shown to exhibit immunomodulatory properties with inhibition of proinflammatory response in both TDM stimulated or Mtb-infected bone marrow-derived macrophages and mice [148].

Table 3. Synthetic AMP covered in this review, alongside their sequence, reported activity, and respective source.

\begin{tabular}{|c|c|c|c|c|}
\hline Peptide & Sequence & Activity & Source & Ref. \\
\hline $1-\mathrm{C} 13_{4 \mathrm{mer}}$ & $\begin{array}{l}\text { H-Ntridec-NLys-Nspe-Nspe-NLys, } \\
\text { amidated }\end{array}$ & MIC (H37Rv): $6.6 \mu \mathrm{M}$ & De novo & [138] \\
\hline 1 & $\begin{array}{c}\text { Ac-GF-(A6c)-G-(A6c)-KK-(A6c)-G-(A6c)-F- } \\
\text { (A6c)-G-(A6c)-GKK-(A6c)-KKKK, } \\
\text { amidated }\end{array}$ & MIC (H37Ra, MDR, XDR): $4.92 \mu \mathrm{M}$ & De novo & {$[139]$} \\
\hline $\mathrm{M}(\mathrm{LLKK})_{2} \mathrm{M}$ & MLLKKLLKKM & $\begin{array}{c}\text { MIC (H37Rv): } 125 \mu \mathrm{g} / \mathrm{mL} \\
\text { MIC (MDR CSU87): } 62.5 \mu \mathrm{g} / \mathrm{mL}\end{array}$ & De novo & [140] \\
\hline WKWLKKWIK & WKWLKKWIK & $\mathrm{IC}_{90}$ (lux): $1 \mu \mathrm{M}$ & De novo & [143] \\
\hline $\mathrm{Cin}+\mathrm{CAMP} 1$ & (Cin1)-KWLKKWIK, amidated & $\begin{array}{l}\mathrm{IC}_{50}(\mathrm{H} 37 \mathrm{Rv}): 0.69 \mu \mathrm{M} \\
\mathrm{IC}_{50}(\mathrm{MDR} *): 2.77 \mu \mathrm{M}\end{array}$ & De novo & {$[144]$} \\
\hline $\mathrm{Cin}+\mathrm{CAMP} 3$ & (Cin2)-ARLWWWWRRK, amidated & $\begin{array}{l}\mathrm{IC}_{50}(\mathrm{H} 37 \mathrm{Rv}): 2.41 \mu \mathrm{M} \\
\mathrm{IC}_{50}(\mathrm{MDR} *): 0.60 \mu \mathrm{M}\end{array}$ & De novo & {$[144]$} \\
\hline
\end{tabular}


Table 3. Cont.

\begin{tabular}{|c|c|c|c|c|}
\hline Peptide & Sequence & Activity & Source & Ref. \\
\hline IP-1 & KFLNRFWHWLQLKPGQPMY & $\begin{array}{c}\mathrm{IC}_{50}(\mathrm{H} 37 \mathrm{Rv}): 99.27 \mu \mathrm{M} \\
\mathrm{IC}_{50} \text { (MDR CIBIN99): } 92.66 \mu \mathrm{M}\end{array}$ & De novo & [146] \\
\hline E2 & RIWVIWRR, amidated & $\begin{array}{c}\text { MIC (H37Rv, MDR clinical isolate): } \\
2.6 \mu \mathrm{g} / \mathrm{mL}\end{array}$ & Bactenicin & {$[55]$} \\
\hline E6 & RRWRIVVIRVRR, amidated & $\begin{array}{c}\text { MIC (H37Rv, MDR clinical isolate): } \\
3.2 \mu \mathrm{g} / \mathrm{mL}\end{array}$ & Bactenicin & {$[55]$} \\
\hline $\mathrm{C} 26$ & KWKSFIKKLTSAAKKVVTTAKPLISS & $\begin{array}{c}\text { MIC (H37Rv, MDR clinical isolate): } \\
2.1 \mu \mathrm{g} / \mathrm{mL}\end{array}$ & Bactenicin & {$[55]$} \\
\hline IDR-HH2 & VQLRIRVAVIRA, amidated & MIC (H37Rv): $29.3 \mu \mathrm{g} / \mathrm{mL}^{* *}$ & MCP-1 & [147] \\
\hline IDR-1002 & VQRWLIVWRIRK, amidated & MIC (H37Rv): $29.3 \mu \mathrm{g} / \mathrm{mL}^{* *}$ & MCP-1 & [147] \\
\hline IDR-1018 & VRLIVAVRIWRR, amidated & $\operatorname{MIC}(\mathrm{H} 37 \mathrm{Rv}): 16 \mu \mathrm{g} / \mathrm{mL}^{* *}$ & MCP-1 & [147] \\
\hline Sansanmycin A derivative $1 \mathrm{~d}$ & Not available & MIC (H37Rv, MDR 2199): $8 \mu \mathrm{g} / \mathrm{mL}$ & Sansanmycin A & [128] \\
\hline AK15-6 & AVKKLLRWWSRWWKK & MIC (H37Rv): $18.75 \mu \mathrm{g} / \mathrm{mL}$ & AK15 & [148] \\
\hline
\end{tabular}

A6c: 1-aminocyclohexane carboxylic acid; Cin1: cinnamic acid; Cin2: 2,3-dimetoxycinnamic acid; * —clinical isolate resistant to isoniazid, rifampicin and streptomycin; ${ }^{* *}$ _immunomodulatory activity.

\section{Taking AMPs from Bench to the Clinic}

Antimicrobial peptides, given their multi-functionality, direct killing mechanism, and immunomodulatory properties, provide an attractive pharmacological option not only against $M t b$ but also a wide range of other infections. Therefore, there has been extensive efforts on exploring the possibilities that peptides bring to the table as new therapeutic agents against infectious diseases [149]. However, despite their remarkable properties, AMPs still face major challenges to join the pharmaceutical industry. The primary challenge is the susceptibility to proteolytic enzymes. When administered orally, AMP must overcome enzymes that operate through the digestive tract, like pepsin, trypsin, and chymotrypsin. Intravenous administration poses similar challenges, as there are many proteases in blood [150]. Moreover, intravenous administration translates into a shorter half-life due to hepatic and renal clearances [31]. New design strategies have been applied to overcome these challenges, with the incorporation of non-natural amino acids, backbone mimetics, conjugation with fatty acids, and $N$ and C-terminus modifications [136]. Furthermore, drug delivery systems, using different types of vehicles such as nanoparticles, liposomes, or different gel formulations, have also been a strategy employed to reduce proteolytic degradation [151]. Nanoparticles allow for the protection of peptides, controlled plasma levels, a prolonged and/or controlled release, and reduction of administration frequency. Consequently, all these advantages translate into lower toxicity for the host [152], a major benefit, especially when considering that another challenge that AMP need to surpass is their toxicity towards eukaryotic cells [150]. Given the broad range of activities that AMP possess, continuous large-scale production is required, especially since the availability of those naturally synthesized is rather low. Large-scale synthesis of AMP has been improving, aiming at the future attainment of industrial production levels similar to current ones for small molecule-based medicines. Furthermore, biotechnological fabrication approaches have been developed to enhance the production of AMP such as insertion of recombinant DNA into specific vectors, transgenic expression in plants and the engineering of chloroplasts as bioreactors for AMP synthesis [153,154].

Tuberculosis is still, up to this day, one of the deadliest infectious diseases ever known to mankind. Facing the possibility of losing the fight due to emerging resistance, it is imperative to keep searching for new alternatives to the current treatments. To that end, due to their non-specific mode of action, synthetic and natural AMP, from animal to nonanimal sources, are expected to be the next generation of wide-spectrum antimicrobials. Still, peptides are yet to meet their expectations, mainly due to pharmacokinetic liabilities. Nonetheless, their huge plethora of applications and mechanisms cement their position 
as the next "go-to" anti-infective agents, hopefully useful against formidable pathogens like $M t b$.

Author Contributions: Writing—original draft preparation, G.S.O. and R.P.C.; writing—review and editing, P.G., M.S.G., T.S. and C.T. All authors have read and agreed to the published version of the manuscript.

Funding: This research was funded by Fundação para a Ciência e Tecnologia (FCT), Portugal, through projects UIDB/50006/2020, and PTDC/BTM-SAL/29786/2017.

Institutional Review Board Statement: Not applicable.

Informed Consent Statement: Not applicable.

Data Availability Statement: Not applicable.

Conflicts of Interest: The authors declare no conflict of interest.

\section{References}

1. Furin, J.; Cox, H.; Pai, M. Tuberculosis. Lancet 2019, 393, 1642-1656. [CrossRef]

2. Bruchfeld, J.; Correia-Neves, M.; Kallenius, G. Tuberculosis and HIV Coinfection. Cold Spring Harb. Perspect. Med. 2015, 5, a017871. [CrossRef]

3. Bourzac, K. Infectious disease: Beating the big three. Nature 2014, 507, S4-S7. [CrossRef]

4. WHO. Global Tuberculosis Report 2020. Available online: https://www.who.int/publications/i/item/9789240013131 (accessed on 28 January 2021).

5. Kurz, S.G.; Furin, J.J; Bark, C.M. Drug-Resistant Tuberculosis: Challenges and Progress. Infect. Dis. Clin. N. Am. 2016, 30, 509-522. [CrossRef]

6. Chan, E.D.; Iseman, M.D. Multidrug-resistant and extensively drug-resistant tuberculosis: A review. Curr. Opin. Infect. Dis. 2008, 21, 587-595. [CrossRef]

7. Usmani, S.S.; Kumar, R.; Kumar, V.; Singh, S.; Raghava, G.P.S. AntiTbPdb: A knowledgebase of anti-tubercular peptides. Database 2018, 2018. [CrossRef] [PubMed]

8. Silva, J.P.; Appelberg, R.; Gama, F.M. Antimicrobial peptides as novel anti-tuberculosis therapeutics. Biotechnol. Adv. 2016, 34, 924-940. [CrossRef]

9. Fox, J.L. Antimicrobial peptides stage a comeback. Nat. Biotechnol. 2013, 31, 379-382. [CrossRef] [PubMed]

10. Pai, M.; Behr, M.A.; Dowdy, D.; Dheda, K.; Divangahi, M.; Boehme, C.C.; Ginsberg, A.; Swaminathan, S.; Spigelman, M.; Getahun, H.; et al. Tuberculosis. Nat. Rev. Dis. Primers 2016, 2, 16076. [CrossRef] [PubMed]

11. Russell, D.G. Mycobacterium tuberculosis and the intimate discourse of a chronic infection. Immunol. Rev. 2011, 240, 252-268. [CrossRef] [PubMed]

12. Wolf, A.J.; Desvignes, L.; Linas, B.; Banaiee, N.; Tamura, T.; Takatsu, K.; Ernst, J.D. Initiation of the adaptive immune response to Mycobacterium tuberculosis depends on antigen production in the local lymph node, not the lungs. J. Exp. Med. 2008, 205, 105-115. [CrossRef] [PubMed]

13. Samstein, M.; Schreiber, H.A.; Leiner, I.M.; Susac, B.; Glickman, M.S.; Pamer, E.G. Essential yet limited role for CCR2(+) inflammatory monocytes during Mycobacterium tuberculosis-specific T cell priming. eLife 2013, 2, e01086. [CrossRef] [PubMed]

14. Silva Miranda, M.; Breiman, A.; Allain, S.; Deknuydt, F.; Altare, F. The tuberculous granuloma: An unsuccessful host defence mechanism providing a safety shelter for the bacteria? Clin. Dev. Immunol. 2012, 2012, 139127. [CrossRef] [PubMed]

15. Qualls, J.E.; Murray, P.J. Immunometabolism within the tuberculosis granuloma: Amino acids, hypoxia, and cellular respiration. Semin. Immunopathol. 2016, 38, 139-152. [CrossRef] [PubMed]

16. Gengenbacher, M.; Kaufmann, S.H. Mycobacterium tuberculosis: Success through dormancy. FEMS Microbiol. Rev. 2012, 36, 514-532. [CrossRef]

17. Jarlier, V.; Nikaido, H. Mycobacterial cell wall: Structure and role in natural resistance to antibiotics. FEMS Microbiol. Lett. 1994, 123, 11-18. [CrossRef]

18. Kolattukudy, P.E.; Fernandes, N.D.; Azad, A.K.; Fitzmaurice, A.M.; Sirakova, T.D. Biochemistry and molecular genetics of cell-wall lipid biosynthesis in mycobacteria. Mol. Microbiol. 1997, 24, 263-270. [CrossRef]

19. Mangtani, P.; Abubakar, I.; Ariti, C.; Beynon, R.; Pimpin, L.; Fine, P.E.; Rodrigues, L.C.; Smith, P.G.; Lipman, M.; Whiting, P.F.; et al. Protection by BCG vaccine against tuberculosis: A systematic review of randomized controlled trials. Clin. Infect. Dis. 2014, 58, 470-480. [CrossRef]

20. Onyebujoh, P.; Zumla, A.; Ribeiro, I.; Rustomjee, R.; Mwaba, P.; Gomes, M.; Grange, J.M. Treatment of tuberculosis: Present status and future prospects. Bull. World Health Organ. 2005, 83, 857-865. [CrossRef]

21. Vilchèze, C. Mycobacterial Cell Wall: A Source of Successful Targets for Old and New Drugs. Appl. Sci. 2020, 10, 2278. [CrossRef]

22. Wehrli, W. Rifampin: Mechanisms of action and resistance. Rev. Infect. Dis. 1983, 5 (Suppl. 3), S407-S411. [CrossRef] [PubMed] 
23. Zhang, Y.; Wade, M.M.; Scorpio, A.; Zhang, H.; Sun, Z. Mode of action of pyrazinamide: Disruption of Mycobacterium tuberculosis membrane transport and energetics by pyrazinoic acid. J. Antimicrob. Chemother. 2003, 52, 790-795. [CrossRef] [PubMed]

24. Sosnik, A.; Carcaboso, A.M.; Glisoni, R.J.; Moretton, M.A.; Chiappetta, D.A. New old challenges in tuberculosis: Potentially effective nanotechnologies in drug delivery. Adv. Drug Deliv. Rev. 2010, 62, 547-559. [CrossRef] [PubMed]

25. Loddenkemper, R.; Sagebiel, D.; Brendel, A. Strategies against multidrug-resistant tuberculosis. Eur. Respir. J. Suppl. 2002, 36, 66s-77s. [CrossRef] [PubMed]

26. Jang, J.G.; Chung, J.H. Diagnosis and treatment of multidrug-resistant tuberculosis. Yeungnam Univ. J. Med. 2020, 37, 277-285. [CrossRef] [PubMed]

27. Haney, E.F.; Straus, S.K.; Hancock, R.E.W. Reassessing the Host Defense Peptide Landscape. Front. Chem. 2019, 7, 43. [CrossRef]

28. Padhi, A.; Sengupta, M.; Sengupta, S.; Roehm, K.H.; Sonawane, A. Antimicrobial peptides and proteins in mycobacterial therapy: Current status and future prospects. Tuberculosis 2014, 94, 363-373. [CrossRef] [PubMed]

29. Magana, M.; Pushpanathan, M.; Santos, A.L.; Leanse, L.; Fernandez, M.; Ioannidis, A.; Giulianotti, M.A.; Apidianakis, Y.; Bradfute, S.; Ferguson, A.L.; et al. The value of antimicrobial peptides in the age of resistance. Lancet Infect. Dis. 2020, 20, e216-e230. [CrossRef]

30. Gaglione, R.; Pizzo, E.; Notomista, E.; de la Fuente-Nunez, C.; Arciello, A. Host Defence Cryptides from Human Apolipoproteins: Applications in Medicinal Chemistry. Curr. Top. Med. Chem. 2020, 20, 1324-1337. [CrossRef]

31. Mahlapuu, M.; Hakansson, J.; Ringstad, L.; Bjorn, C. Antimicrobial Peptides: An Emerging Category of Therapeutic Agents. Front. Cell. Infect. Microbiol. 2016, 6, 194. [CrossRef]

32. Hancock, R.E.; Sahl, H.G. Antimicrobial and host-defense peptides as new anti-infective therapeutic strategies. Nat. Biotechnol. 2006, 24, 1551-1557. [CrossRef] [PubMed]

33. Sohlenkamp, C.; Geiger, O. Bacterial membrane lipids: Diversity in structures and pathways. FEMS Microbiol. Rev. 2016, 40, 133-159. [CrossRef]

34. Lee, T.H.; Hall, K.N.; Aguilar, M.I. Antimicrobial Peptide Structure and Mechanism of Action: A Focus on the Role of Membrane Structure. Curr. Top. Med. Chem. 2016, 16, 25-39. [CrossRef]

35. Dathe, M.; Nikolenko, H.; Meyer, J.; Beyermann, M.; Bienert, M. Optimization of the antimicrobial activity of magainin peptides by modification of charge. FEBS Lett. 2001, 501, 146-150. [CrossRef]

36. Jiang, Z.; Vasil, A.I.; Hale, J.D.; Hancock, R.E.; Vasil, M.L.; Hodges, R.S. Effects of net charge and the number of positively charged residues on the biological activity of amphipathic alpha-helical cationic antimicrobial peptides. Biopolymers 2008, 90, 369-383. [CrossRef] [PubMed]

37. Matsuzaki, K. Control of cell selectivity of antimicrobial peptides. Biochim. Biophys. Acta 2009, 1788, 1687-1692. [CrossRef]

38. Haney, E.F.; Mansour, S.C.; Hancock, R.E. Antimicrobial Peptides: An Introduction. Methods Mol. Biol. 2017, 1548, 3-22. [CrossRef] [PubMed]

39. Vale, N.; Aguiar, L.; Gomes, P. Antimicrobial peptides: A new class of antimalarial drugs? Front. Pharmacol. 2014, 5, 275. [CrossRef]

40. Yeaman, M.R.; Yount, N.Y. Mechanisms of antimicrobial peptide action and resistance. Pharmacol. Rev. 2003, 55, 27-55. [CrossRef] [PubMed]

41. Nguyen, L.T.; Haney, E.F.; Vogel, H.J. The expanding scope of antimicrobial peptide structures and their modes of action. Trends Biotechnol. 2011, 29, 464-472. [CrossRef] [PubMed]

42. Kumar, P.; Kizhakkedathu, J.N.; Straus, S.K. Antimicrobial Peptides: Diversity, Mechanism of Action and Strategies to Improve the Activity and Biocompatibility In Vivo. Biomolecules 2018, 8, 4. [CrossRef] [PubMed]

43. Zasloff, M. Antimicrobial peptides of multicellular organisms. Nature 2002, 415, 389-395. [CrossRef] [PubMed]

44. Silva, T.; Gomes, M.S. Immuno-Stimulatory Peptides as a Potential Adjunct Therapy against Intra-Macrophagic Pathogens. Molecules 2017, 22, 1297. [CrossRef] [PubMed]

45. Lei, J.; Sun, L.; Huang, S.; Zhu, C.; Li, P.; He, J.; Mackey, V.; Coy, D.H.; He, Q. The antimicrobial peptides and their potential clinical applications. Am. J. Transl. Res. 2019, 11, 3919-3931.

46. Hemshekhar, M.; Anaparti, V.; Mookherjee, N. Functions of Cationic Host Defense Peptides in Immunity. Pharmaceuticals 2016, 9 , 40. [CrossRef] [PubMed]

47. Kosciuczuk, E.M.; Lisowski, P.; Jarczak, J.; Strzalkowska, N.; Jozwik, A.; Horbanczuk, J.; Krzyzewski, J.; Zwierzchowski, L.; Bagnicka, E. Cathelicidins: Family of antimicrobial peptides. A review. Mol. Biol. Rep. 2012, 39, 10957-10970. [CrossRef] [PubMed]

48. Zanetti, M. The role of cathelicidins in the innate host defenses of mammals. Curr. Issues Mol. Biol. 2005, 7, 179-196.

49. Sonawane, A.; Santos, J.C.; Mishra, B.B.; Jena, P.; Progida, C.; Sorensen, O.E.; Gallo, R.; Appelberg, R.; Griffiths, G. Cathelicidin is involved in the intracellular killing of mycobacteria in macrophages. Cell Microbiol. 2011, 13, 1601-1617. [CrossRef]

50. Durr, U.H.; Sudheendra, U.S.; Ramamoorthy, A. LL-37, the only human member of the cathelicidin family of antimicrobial peptides. Biochim. Biophys. Acta 2006, 1758, 1408-1425. [CrossRef]

51. Yang, B.; Good, D.; Mosaiab, T.; Liu, W.; Ni, G.; Kaur, J.; Liu, X.; Jessop, C.; Yang, L.; Fadhil, R.; et al. Significance of LL-37 on Immunomodulation and Disease Outcome. Biomed. Res. Int. 2020, 2020, 8349712. [CrossRef] 
52. Liu, P.T.; Stenger, S.; Li, H.; Wenzel, L.; Tan, B.H.; Krutzik, S.R.; Ochoa, M.T.; Schauber, J.; Wu, K.; Meinken, C.; et al. Toll-like receptor triggering of a vitamin D-mediated human antimicrobial response. Science 2006, 311, 1770-1773. [CrossRef] [PubMed]

53. Mily, A.; Rekha, R.S.; Kamal, S.M.; Arifuzzaman, A.S.; Rahim, Z.; Khan, L.; Haq, M.A.; Zaman, K.; Bergman, P.; Brighenti, S.; et al. Significant Effects of Oral Phenylbutyrate and Vitamin D3 Adjunctive Therapy in Pulmonary Tuberculosis: A Randomized Controlled Trial. PLoS ONE 2015, 10, e0138340. [CrossRef] [PubMed]

54. Rivas-Santiago, B.; Hernandez-Pando, R.; Carranza, C.; Juarez, E.; Contreras, J.L.; Aguilar-Leon, D.; Torres, M.; Sada, E. Expression of cathelicidin LL-37 during Mycobacterium tuberculosis infection in human alveolar macrophages, monocytes, neutrophils, and epithelial cells. Infect. Immun. 2008, 76, 935-941. [CrossRef] [PubMed]

55. Rivas-Santiago, B.; Rivas Santiago, C.E.; Castaneda-Delgado, J.E.; Leon-Contreras, J.C.; Hancock, R.E.; Hernandez-Pando, R. Activity of LL-37, CRAMP and antimicrobial peptide-derived compounds E2, E6 and CP26 against Mycobacterium tuberculosis. Int. J. Antimicrob. Agents 2013, 41, 143-148. [CrossRef] [PubMed]

56. Torres-Juarez, F.; Cardenas-Vargas, A.; Montoya-Rosales, A.; Gonzalez-Curiel, I.; Garcia-Hernandez, M.H.; Enciso-Moreno, J.A.; Hancock, R.E.; Rivas-Santiago, B. LL-37 immunomodulatory activity during Mycobacterium tuberculosis infection in macrophages. Infect. Immun. 2015, 83, 4495-4503. [CrossRef] [PubMed]

57. Wessely-Szponder, J.; Majer-Dziedzic, B.; Smolira, A. Analysis of antimicrobial peptides from porcine neutrophils. J. Microbiol. Methods 2010, 83, 8-12. [CrossRef]

58. Storici, P.; Zanetti, M. A cDNA derived from pig bone marrow cells predicts a sequence identical to the intestinal antibacterial peptide PR-39. Biochem. Biophys. Res. Commun. 1993, 196, 1058-1065. [CrossRef]

59. Shi, J.; Ross, C.R.; Chengappa, M.M.; Blecha, F. Identification of a proline-arginine-rich antibacterial peptide from neutrophils that is analogous to PR-39, an antibacterial peptide from the small intestine. J. Leukoc. Biol. 1994, 56, 807-811. [CrossRef]

60. Boman, H.G.; Agerberth, B.; Boman, A. Mechanisms of action on Escherichia coli of cecropin P1 and PR-39, two antibacterial peptides from pig intestine. Infect. Immun. 1993, 61, 2978-2984. [CrossRef]

61. Linde, C.M.; Hoffner, S.E.; Refai, E.; Andersson, M. In vitro activity of PR-39, a proline-arginine-rich peptide, against susceptible and multi-drug-resistant Mycobacterium tuberculosis. J. Antimicrob. Chemother. 2001, 47, 575-580. [CrossRef]

62. Portell-Buj, E.; Vergara, A.; Alejo, I.; Lopez-Gavin, A.; Monte, M.R.; San Nicolas, L.; Gonzalez-Martin, J.; Tudo, G. In vitro activity of 12 antimicrobial peptides against Mycobacterium tuberculosis and Mycobacterium avium clinical isolates. J. Med. Microbiol. 2019, 68, 211-215. [CrossRef] [PubMed]

63. Xu, D.; Lu, W. Defensins: A Double-Edged Sword in Host Immunity. Front. Immunol. 2020, 11, 764. [CrossRef] [PubMed]

64. Dong, H.; Lv, Y.; Zhao, D.; Barrow, P.; Zhou, X. Defensins: The Case for Their Use against Mycobacterial Infections. J. Immunol. Res. 2016, 2016, 7515687. [CrossRef] [PubMed]

65. Amerikova, M.; Pencheva El-Tibi, I.; Maslarska, V.; Bozhanov, S.; Tachkov, K. Antimicrobial activity, mechanism of action, and methods for stabilisation of defensins as new therapeutic agents. Biotechnol. Biotechnol. Equip. 2019, 33, 671-682. [CrossRef]

66. Ganz, T. Defensins: Antimicrobial peptides of innate immunity. Nat. Rev. Immunol. 2003, 3, 710-720. [CrossRef]

67. Machado, L.R.; Ottolini, B. An evolutionary history of defensins: A role for copy number variation in maximizing host innate and adaptive immune responses. Front. Immunol. 2015, 6, 115. [CrossRef]

68. Rivas-Santiago, B.; Schwander, S.K.; Sarabia, C.; Diamond, G.; Klein-Patel, M.E.; Hernandez-Pando, R.; Ellner, J.J.; Sada, E. Human \{beta\}-defensin 2 is expressed and associated with Mycobacterium tuberculosis during infection of human alveolar epithelial cells. Infect. Immun. 2005, 73, 4505-4511. [CrossRef]

69. Rivas-Santiago, C.E.; Rivas-Santiago, B.; Leon, D.A.; Castaneda-Delgado, J.; Hernandez Pando, R. Induction of beta-defensins by 1-isoleucine as novel immunotherapy in experimental murine tuberculosis. Clin. Exp. Immunol. 2011, 164, 80-89. [CrossRef]

70. Fattorini, L.; Gennaro, R.; Zanetti, M.; Tan, D.; Brunori, L.; Giannoni, F.; Pardini, M.; Orefici, G. In vitro activity of protegrin-1 and beta-defensin-1, alone and in combination with isoniazid, against Mycobacterium tuberculosis. Peptides 2004, 25, $1075-1077$. [CrossRef] [PubMed]

71. Ashitani, J.; Mukae, H.; Hiratsuka, T.; Nakazato, M.; Kumamoto, K.; Matsukura, S. Elevated levels of alpha-defensins in plasma and BAL fluid of patients with active pulmonary tuberculosis. Chest 2002, 121, 519-526. [CrossRef]

72. Jacobsen, M.; Repsilber, D.; Gutschmidt, A.; Neher, A.; Feldmann, K.; Mollenkopf, H.J.; Ziegler, A.; Kaufmann, S.H. Candidate biomarkers for discrimination between infection and disease caused by Mycobacterium tuberculosis. J. Mol. Med. 2007, 85, 613-621. [CrossRef] [PubMed]

73. Sharma, S.; Verma, I.; Khuller, G.K. Therapeutic potential of human neutrophil peptide 1 against experimental tuberculosis. Antimicrob. Agents Chemother. 2001, 45, 639-640. [CrossRef]

74. Kalita, A.; Verma, I.; Khuller, G.K. Role of human neutrophil peptide-1 as a possible adjunct to antituberculosis chemotherapy. J. Infect. Dis. 2004, 190, 1476-1480. [CrossRef]

75. Sharma, R.; Raghav, R.; Priyanka, K.; Rishi, P.; Sharma, S.; Srivastava, S.; Verma, I. Exploiting chitosan and gold nanoparticles for antimycobacterial activity of in silico identified antimicrobial motif of human neutrophil peptide-1. Sci. Rep. 2019, 9, 7866. [CrossRef]

76. Zhao, C.; Ganz, T.; Lehrer, R.I. The structure of porcine protegrin genes. FEBS Lett. 1995, 368, 197-202. [CrossRef]

77. Fahrner, R.L.; Dieckmann, T.; Harwig, S.S.; Lehrer, R.I.; Eisenberg, D.; Feigon, J. Solution structure of protegrin-1, a broad-spectrum antimicrobial peptide from porcine leukocytes. Chem. Biol. 1996, 3, 543-550. [CrossRef] 
78. Aumelas, A.; Mangoni, M.; Roumestand, C.; Chiche, L.; Despaux, E.; Grassy, G.; Calas, B.; Chavanieu, A. Synthesis and solution structure of the antimicrobial peptide protegrin-1. Eur. J. Biochem. 1996, 237, 575-583. [CrossRef]

79. Andrews, S.C.; Robinson, A.K.; Rodriguez-Quinones, F. Bacterial iron homeostasis. FEMS Microbiol. Rev. 2003, 27, 215-237. [CrossRef]

80. Malyszko, J.; Tesar, V.; Macdougall, I.C. Neutrophil gelatinase-associated lipocalin and hepcidin: What do they have in common and is there a potential interaction? Kidney Blood Press Res. 2010, 33, 157-165. [CrossRef]

81. Nemeth, E.; Ganz, T. The role of hepcidin in iron metabolism. Acta Haematol. 2009, 122, 78-86. [CrossRef]

82. Gomes, A.C.; Moreira, A.C.; Mesquita, G.; Gomes, M.S. Modulation of Iron Metabolism in Response to Infection: Twists for All Tastes. Pharmaceuticals 2018, 11, 84. [CrossRef] [PubMed]

83. Sow, F.B.; Florence, W.C.; Satoskar, A.R.; Schlesinger, L.S.; Zwilling, B.S.; Lafuse, W.P. Expression and localization of hepcidin in macrophages: A role in host defense against tuberculosis. J. Leukoc. Biol. 2007, 82, 934-945. [CrossRef] [PubMed]

84. Harrington-Kandt, R.; Stylianou, E.; Eddowes, L.A.; Lim, P.J.; Stockdale, L.; Pinpathomrat, N.; Bull, N.; Pasricha, J.; Ulaszewska, M.; Beglov, Y.; et al. Hepcidin deficiency and iron deficiency do not alter tuberculosis susceptibility in a murine M.tb infection model. PLoS ONE 2018, 13, e0191038. [CrossRef] [PubMed]

85. Caccavo, D.; Pellegrino, N.M.; Altamura, M.; Rigon, A.; Amati, L.; Amoroso, A.; Jirillo, E. Antimicrobial and immunoregulatory functions of lactoferrin and its potential therapeutic application. J. Endotoxin Res. 2002, 8, 403-417. [CrossRef]

86. Bruni, N.; Capucchio, M.T.; Biasibetti, E.; Pessione, E.; Cirrincione, S.; Giraudo, L.; Corona, A.; Dosio, F. Antimicrobial Activity of Lactoferrin-Related Peptides and Applications in Human and Veterinary Medicine. Molecules 2016, 21, 752. [CrossRef]

87. Koo, H.; Seo, J. Antimicrobial peptides under clinical investigation. Pept. Sci. 2019, 111. [CrossRef]

88. Silva, T.; Moreira, A.C.; Nazmi, K.; Moniz, T.; Vale, N.; Rangel, M.; Gomes, P.; Bolscher, J.G.M.; Rodrigues, P.N.; Bastos, M.; et al. Lactoferricin Peptides Increase Macrophages' Capacity To Kill Mycobacterium avium. mSphere 2017, 2. [CrossRef]

89. Silva, T.; Magalhaes, B.; Maia, S.; Gomes, P.; Nazmi, K.; Bolscher, J.G.; Rodrigues, P.N.; Bastos, M.; Gomes, M.S. Killing of Mycobacterium avium by lactoferricin peptides: Improved activity of arginine- and D-amino-acid-containing molecules. Antimicrob. Agents Chemother. 2014, 58, 3461-3467. [CrossRef]

90. Fornili, S.L.; Pizzi, R.; Rebeccani, D. Conformational Analysis of a Synthetic Antimicrobial Peptide in Water and MembraneMimicking Solvents: A Molecular Dynamics Simulation Study. Int. J. Pept. Res. Ther. 2010, 16, 223-231. [CrossRef]

91. Welsh, K.J.; Hwang, S.A.; Boyd, S.; Kruzel, M.L.; Hunter, R.L.; Actor, J.K. Influence of oral lactoferrin on Mycobacterium tuberculosis induced immunopathology. Tuberculosis 2011, 91 (Suppl. 1), S105-S113. [CrossRef]

92. Hwang, S.A.; Wilk, K.M.; Bangale, Y.A.; Kruzel, M.L.; Actor, J.K. Lactoferrin modulation of IL-12 and IL-10 response from activated murine leukocytes. Med. Microbiol. Immunol. 2007, 196, 171-180. [CrossRef] [PubMed]

93. Hwang, S.A.; Kruzel, M.L.; Actor, J.K. CHO expressed recombinant human lactoferrin as an adjuvant for BCG. Int. J. Immunopathol. Pharmacol. 2015, 28, 452-468. [CrossRef] [PubMed]

94. Thom, R.E.; Elmore, M.J.; Williams, A.; Andrews, S.C.; Drobniewski, F.; Marsh, P.D.; Tree, J.A. The expression of ferritin, lactoferrin, transferrin receptor and solute carrier family 11A1 in the host response to BCG-vaccination and Mycobacterium tuberculosis challenge. Vaccine 2012, 30, 3159-3168. [CrossRef] [PubMed]

95. Malhotra, H.; Patidar, A.; Boradia, V.M.; Kumar, R.; Nimbalkar, R.D.; Kumar, A.; Gani, Z.; Kaur, R.; Garg, P.; Raje, M.; et al. Mycobacterium tuberculosis Glyceraldehyde-3-Phosphate Dehydrogenase (GAPDH) Functions as a Receptor for Human Lactoferrin. Front. Cell. Infect. Microbiol. 2017, 7, 245. [CrossRef]

96. Komander, D.; Rape, M. The ubiquitin code. Annu. Rev. Biochem. 2012, 81, 203-229. [CrossRef]

97. Hicke, L.; Schubert, H.L.; Hill, C.P. Ubiquitin-binding domains. Nat. Rev. Mol. Cell Biol. 2005, 6, 610-621. [CrossRef]

98. Teng, T.; Liu, J.; Wei, H. Anti-mycobacterial peptides: From human to phage. Cell. Physiol. Biochem. 2015, 35, 452-466. [CrossRef]

99. Alonso, S.; Pethe, K.; Russell, D.G.; Purdy, G.E. Lysosomal killing of Mycobacterium mediated by ubiquitin-derived peptides is enhanced by autophagy. Proc. Natl. Acad. Sci. USA 2007, 104, 6031-6036. [CrossRef]

100. Foss, M.H.; Powers, K.M.; Purdy, G.E. Structural and functional characterization of mycobactericidal ubiquitin-derived peptides in model and bacterial membranes. Biochemistry 2012, 51, 9922-9929. [CrossRef]

101. Purdy, G.E.; Niederweis, M.; Russell, D.G. Decreased outer membrane permeability protects mycobacteria from killing by ubiquitin-derived peptides. Mol. Microbiol. 2009, 73, 844-857. [CrossRef] [PubMed]

102. Samuchiwal, S.K.; Tousif, S.; Singh, D.K.; Kumar, A.; Ghosh, A.; Bhalla, K.; Prakash, P.; Kumar, S.; Bhattacharyya, M.; Moodley, P.; et al. A peptide fragment from the human COX3 protein disrupts association of Mycobacterium tuberculosis virulence proteins ESAT-6 and CFP10, inhibits mycobacterial growth and mounts protective immune response. BMC Infect. Dis. $2014,14,355$. [CrossRef] [PubMed]

103. Sreejit, G.; Ahmed, A.; Parveen, N.; Jha, V.; Valluri, V.L.; Ghosh, S.; Mukhopadhyay, S. The ESAT-6 protein of Mycobacterium tuberculosis interacts with beta-2-microglobulin (beta2M) affecting antigen presentation function of macrophage. PLoS Pathog. 2014, 10, e1004446. [CrossRef] [PubMed]

104. Stapels, D.A.; Geisbrecht, B.V.; Rooijakkers, S.H. Neutrophil serine proteases in antibacterial defense. Curr. Opin. Microbiol. 2015, 23, 42-48. [CrossRef] [PubMed]

105. Mutua, V.; Gershwin, L.J. A Review of Neutrophil Extracellular Traps (NETs) in Disease: Potential Anti-NETs Therapeutics. Clin. Rev. Allergy Immunol. 2020. [CrossRef] [PubMed] 
106. Rivera-Marrero, C.A.; Stewart, J.; Shafer, W.M.; Roman, J. The down-regulation of cathepsin G in THP-1 monocytes after infection with Mycobacterium tuberculosis is associated with increased intracellular survival of bacilli. Infect. Immun. 2004, 72, 5712-5721. [CrossRef]

107. Hmed, B.; Serria, H.T.; Mounir, Z.K. Scorpion peptides: Potential use for new drug development. J. Toxicol. 2013, $2013,958797$. [CrossRef] [PubMed]

108. Ramirez-Carreto, S.; Jimenez-Vargas, J.M.; Rivas-Santiago, B.; Corzo, G.; Possani, L.D.; Becerril, B.; Ortiz, E. Peptides from the scorpion Vaejovis punctatus with broad antimicrobial activity. Peptides 2015, 73, 51-59. [CrossRef]

109. Rodriguez, A.; Villegas, E.; Montoya-Rosales, A.; Rivas-Santiago, B.; Corzo, G. Characterization of antibacterial and hemolytic activity of synthetic pandinin 2 variants and their inhibition against Mycobacterium tuberculosis. PLoS ONE 2014, 9, e101742. [CrossRef]

110. Xie, J.P.; Yue, J.; Xiong, Y.L.; Wang, W.Y.; Yu, S.Q.; Wang, H.H. In vitro activities of small peptides from snake venom against clinical isolates of drug-resistant Mycobacterium tuberculosis. Int. J. Antimicrob. Agents 2003, 22, 172-174. [CrossRef]

111. Morikawa, N.; Hagiwara, K.; Nakajima, T. Brevinin-1 and -2, unique antimicrobial peptides from the skin of the frog, Rana brevipoda porsa. Biochem. Biophys. Res. Commun. 1992, 189, 184-190. [CrossRef]

112. Abraham, P.; Jose, L.; Maliekal, T.T.; Kumar, R.A.; Kumar, K.S. B1CTcu5: A frog-derived brevinin-1 peptide with anti-tuberculosis activity. Peptides 2020, 132, 170373. [CrossRef] [PubMed]

113. Donaghy, J. Lantibiotics as prospective antimycobacterial agents. Bioeng. Bugs 2010, 1, 437-439. [CrossRef] [PubMed]

114. de Arauz, L.J.; Jozala, A.F.; Mazzola, P.G.; Vessoni Penna, T.C. Nisin biotechnological production and application: A review. Trends Food Sci. Technol. 2009, 20, 146-154. [CrossRef]

115. Suda, S.; Cotter, P.D.; Hill, C.; Ross, R.P. Lacticin 3147-biosynthesis, molecular analysis, immunity, bioengineering and applications. Curr. Protein Pept. Sci. 2012, 13, 193-204. [CrossRef] [PubMed]

116. Carroll, J.; Draper, L.A.; O'Connor, P.M.; Coffey, A.; Hill, C.; Ross, R.P.; Cotter, P.D.; O'Mahony, J. Comparison of the activities of the lantibiotics nisin and lacticin 3147 against clinically significant mycobacteria. Int. J. Antimicrob. Agents 2010, 36, 132-136. [CrossRef] [PubMed]

117. Carroll, J.; Field, D.; O'Connor, P.M.; Cotter, P.D.; Coffey, A.; Hill, C.; Ross, R.P.; O’Mahony, J. Gene encoded antimicrobial peptides, a template for the design of novel anti-mycobacterial drugs. Bioeng. Bugs 2010, 1, 408-412. [CrossRef]

118. Ghobrial, O.; Derendorf, H.; Hillman, J.D. Pharmacokinetic and pharmacodynamic evaluation of the lantibiotic MU1140. J. Pharm. Sci. 2010, 99, 2521-2528. [CrossRef]

119. Hillman, J.D.; Novak, J.; Sagura, E.; Gutierrez, J.A.; Brooks, T.A.; Crowley, P.J.; Hess, M.; Azizi, A.; Leung, K.; Cvitkovitch, D.; et al. Genetic and biochemical analysis of mutacin 1140, a lantibiotic from Streptococcus mutans. Infect. Immun. 1998, 66, 2743-2749. [CrossRef]

120. Smith, L.; Hasper, H.; Breukink, E.; Novak, J.; Cerkasov, J.; Hillman, J.D.; Wilson-Stanford, S.; Orugunty, R.S. Elucidation of the antimicrobial mechanism of mutacin 1140. Biochemistry 2008, 47, 3308-3314. [CrossRef]

121. Zhu, S.; Su, Y.; Shams, S.; Feng, Y.; Tong, Y.; Zheng, G. Lassomycin and lariatin lasso peptides as suitable antibiotics for combating mycobacterial infections: Current state of biosynthesis and perspectives for production. Appl. Microbiol. Biotechnol. 2019, 103, 3931-3940. [CrossRef]

122. Gavrish, E.; Sit, C.S.; Cao, S.; Kandror, O.; Spoering, A.; Peoples, A.; Ling, L.; Fetterman, A.; Hughes, D.; Bissell, A.; et al. Lassomycin, a ribosomally synthesized cyclic peptide, kills mycobacterium tuberculosis by targeting the ATP-dependent protease ClpC1P1P2. Chem. Biol. 2014, 21, 509-518. [CrossRef] [PubMed]

123. Iwatsuki, M.; Uchida, R.; Takakusagi, Y.; Matsumoto, A.; Jiang, C.L.; Takahashi, Y.; Arai, M.; Kobayashi, S.; Matsumoto, M.; Inokoshi, J.; et al. Lariatins, novel anti-mycobacterial peptides with a lasso structure, produced by Rhodococcus jostii K01-B0171. J. Antibiot. 2007, 60, 357-363. [CrossRef] [PubMed]

124. Shoji, J.; Sakazaki, R. A new peptide antibiotic complex S-520. II. Further characterization and degradative studies. J. Antibiot. 1970, 23, 432-436. [CrossRef] [PubMed]

125. Cohen, K.A.; Stott, K.E.; Munsamy, V.; Manson, A.L.; Earl, A.M.; Pym, A.S. Evidence for Expanding the Role of Streptomycin in the Management of Drug-Resistant Mycobacterium tuberculosis. Antimicrob. Agents Chemother. 2020, 64. [CrossRef]

126. Cai, G.; Napolitano, J.G.; McAlpine, J.B.; Wang, Y.; Jaki, B.U.; Suh, J.W.; Yang, S.H.; Lee, I.A.; Franzblau, S.G.; Pauli, G.F.; et al. Hytramycins V and I, anti-Mycobacterium tuberculosis hexapeptides from a Streptomyces hygroscopicus strain. J. Nat. Prod. 2013, 76, 2009-2018. [CrossRef]

127. Schmitt, E.K.; Riwanto, M.; Sambandamurthy, V.; Roggo, S.; Miault, C.; Zwingelstein, C.; Krastel, P.; Noble, C.; Beer, D.; Rao, S.P.; et al. The natural product cyclomarin kills Mycobacterium tuberculosis by targeting the $\mathrm{ClpC} 1$ subunit of the caseinolytic protease. Angew. Chem. Int. Ed. Engl. 2011, 50, 5889-5891. [CrossRef]

128. Li, Y.B.; Xie, Y.Y.; Du, N.N.; Lu, Y.; Xu, H.Z.; Wang, B.; Yu, Y.; Liu, Y.X.; Song, D.Q.; Chen, R.X. Synthesis and in vitro antitubercular evaluation of novel sansanmycin derivatives. Bioorg. Med. Chem. Lett. 2011, 21, 6804-6807. [CrossRef]

129. Tenland, E.; Krishnan, N.; Ronnholm, A.; Kalsum, S.; Puthia, M.; Morgelin, M.; Davoudi, M.; Otrocka, M.; Alaridah, N.; GlegolaMadejska, I.; et al. A novel derivative of the fungal antimicrobial peptide plectasin is active against Mycobacterium tuberculosis. Tuberculosis 2018, 113, 231-238. [CrossRef] 
130. Pruksakorn, P.; Arai, M.; Kotoku, N.; Vilcheze, C.; Baughn, A.D.; Moodley, P.; Jacobs, W.R., Jr.; Kobayashi, M. Trichoderins, novel aminolipopeptides from a marine sponge-derived Trichoderma sp., are active against dormant mycobacteria. Bioorg. Med. Chem. Lett. 2010, 20, 3658-3663. [CrossRef]

131. Pruksakorn, P.; Arai, M.; Liu, L.; Moodley, P.; Jacobs, W.R., Jr.; Kobayashi, M. Action-mechanism of trichoderin A, an anti-dormant mycobacterial aminolipopeptide from marine sponge-derived Trichoderma sp. Biol. Pharm. Bull. 2011, 34, 1287-1290. [CrossRef]

132. Koffi-Nevry, R.; Kouassi, K.C.; Nanga, Z.Y.; Koussémon, M.; Loukou, G.Y. Antibacterial Activity of Two Bell Pepper Extracts: Capsicum annuum L. and Capsicum frutescens. Int. J. Food Prop. 2012, 15, 961-971. [CrossRef]

133. Santos, M.M.; Vieira-da-Motta, O.; Vieira, I.J.; Braz-Filho, R.; Goncalves, P.S.; Maria, E.J.; Terra, W.S.; Rodrigues, R.; Souza, C.L. Antibacterial activity of Capsicum annuum extract and synthetic capsaicinoid derivatives against Streptococcus mutans. J. Nat. Med. 2012, 66, 354-356. [CrossRef] [PubMed]

134. da Silva Gebara, R.; Taveira, G.B.; de Azevedo Dos Santos, L.; Calixto, S.D.; Simao, T.; Lassounskaia, E.; Muzitano, M.F.; TeixeiraFerreira, A.; Perales, J.; Rodrigues, R.; et al. Identification and Characterization of Two Defensins from Capsicum annuum Fruits that Exhibit Antimicrobial Activity. Probiotics Antimicrob. Proteins 2020, 12, 1253-1265. [CrossRef] [PubMed]

135. Torres, M.D.T.; Sothiselvam, S.; Lu, T.K.; de la Fuente-Nunez, C. Peptide Design Principles for Antimicrobial Applications. J. Mol. Biol. 2019, 431, 3547-3567. [CrossRef]

136. Costa, F.; Teixeira, C.; Gomes, P.; Martins, M.C.L. Clinical Application of AMPs. Adv. Exp. Med. Biol. 2019, 1117, 281-298. [CrossRef]

137. Dohm, M.T.; Kapoor, R.; Barron, A.E. Peptoids: Bio-inspired polymers as potential pharmaceuticals. Curr. Pharm. Des. 2011, 17, 2732-2747. [CrossRef]

138. Kapoor, R.; Eimerman, P.R.; Hardy, J.W.; Cirillo, J.D.; Contag, C.H.; Barron, A.E. Efficacy of antimicrobial peptoids against Mycobacterium tuberculosis. Antimicrob. Agents Chemother. 2011, 55, 3058-3062. [CrossRef]

139. Hicks, R.P. Antibacterial and anticancer activity of a series of novel peptides incorporating cyclic tetra-substituted C(alpha) amino acids. Bioorg. Med. Chem. 2016, 24, 4056-4065. [CrossRef]

140. Khara, J.S.; Wang, Y.; Ke, X.Y.; Liu, S.; Newton, S.M.; Langford, P.R.; Yang, Y.Y.; Ee, P.L. Anti-mycobacterial activities of synthetic cationic alpha-helical peptides and their synergism with rifampicin. Biomaterials 2014, 35, 2032-2038. [CrossRef]

141. Vermeer, L.S.; Lan, Y.; Abbate, V.; Ruh, E.; Bui, T.T.; Wilkinson, L.J.; Kanno, T.; Jumagulova, E.; Kozlowska, J.; Patel, J.; et al. Conformational flexibility determines selectivity and antibacterial, antiplasmodial, and anticancer potency of cationic alpha-helical peptides. J. Biol. Chem. 2012, 287, 34120-34133. [CrossRef]

142. Lan, Y.; Lam, J.T.; Siu, G.K.; Yam, W.C.; Mason, A.J.; Lam, J.K. Cationic amphipathic D-enantiomeric antimicrobial peptides with in vitro and ex vivo activity against drug-resistant Mycobacterium tuberculosis. Tuberculosis 2014, 94, 678-689. [CrossRef]

143. Ramon-Garcia, S.; Mikut, R.; Ng, C.; Ruden, S.; Volkmer, R.; Reischl, M.; Hilpert, K.; Thompson, C.J. Targeting Mycobacterium tuberculosis and other microbial pathogens using improved synthetic antibacterial peptides. Antimicrob. Agents Chemother. 2013, 57, 2295-2303. [CrossRef] [PubMed]

144. Silva, S.; Santos-Silva, A.; da Costa, J.M.C.; Vale, N. Potent cationic antimicrobial peptides against Mycobacterium tuberculosis in vitro. J. Glob. Antimicrob. Resist. 2019, 19, 132-135. [CrossRef] [PubMed]

145. Ellerby, H.M.; Bredesen, D.E.; Fujimura, S.; John, V. Hunter-killer peptide (HKP) for targeted therapy. J. Med. Chem. 2008, 51, 5887-5892. [CrossRef] [PubMed]

146. Pelaez Coyotl, E.A.; Barrios Palacios, J.; Mucino, G.; Moreno-Blas, D.; Costas, M.; Montiel Montes, T.; Diener, C.; Uribe-Carvajal, S.; Massieu, L.; Castro-Obregon, S.; et al. Antimicrobial Peptide against Mycobacterium Tuberculosis That Activates Autophagy Is an Effective Treatment for Tuberculosis. Pharmaceutics 2020, 12, 1071. [CrossRef] [PubMed]

147. Rivas-Santiago, B.; Castaneda-Delgado, J.E.; Rivas Santiago, C.E.; Waldbrook, M.; Gonzalez-Curiel, I.; Leon-Contreras, J.C.; Enciso-Moreno, J.A.; del Villar, V.; Mendez-Ramos, J.; Hancock, R.E.; et al. Ability of innate defence regulator peptides IDR-1002, IDR-HH2 and IDR-1018 to protect against Mycobacterium tuberculosis infections in animal models. PLoS ONE 2013, 8, e59119. [CrossRef]

148. Yang, Y.; Liu, Z.; He, X.; Yang, J.; Wu, J.; Yang, H.; Li, M.; Qian, Q.; Lai, R.; Xu, W.; et al. A small mycobacteriophage-derived peptide and its improved isomer restrict mycobacterial infection via dual mycobactericidal-immunoregulatory activities. J. Biol. Chem. 2019, 294, 7615-7631. [CrossRef]

149. Mendez-Samperio, P. Role of antimicrobial peptides in host defense against mycobacterial infections. Peptides 2008, $29,1836-1841$. [CrossRef]

150. Haney, E.F.; Hancock, R.E. Peptide design for antimicrobial and immunomodulatory applications. Biopolymers 2013, 100, 572-583. [CrossRef]

151. Martin-Serrano, A.; Gomez, R.; Ortega, P.; de la Mata, F.J. Nanosystems as Vehicles for the Delivery of Antimicrobial Peptides (AMPs). Pharmaceutics 2019, 11, 448. [CrossRef]

152. Patel, A.; Cholkar, K.; Mitra, A.K. Recent developments in protein and peptide parenteral delivery approaches. Ther. Deliv. 2014, 5, 337-365. [CrossRef] [PubMed]

153. Sinha, R.; Shukla, P. Antimicrobial Peptides: Recent Insights on Biotechnological Interventions and Future Perspectives. Protein Pept. Lett. 2019, 26, 79-87. [CrossRef] [PubMed]

154. Yevtushenko, D.; Misra, S. Transgenic Expression of Antimicrobial Peptides in Plants: Strategies for Enhanced Disease Resistance, Improved Productivity, and Production of Therapeutics. ACS Symp. Ser. 2012, 1095, 445-458. [CrossRef] 